\title{
Working
}

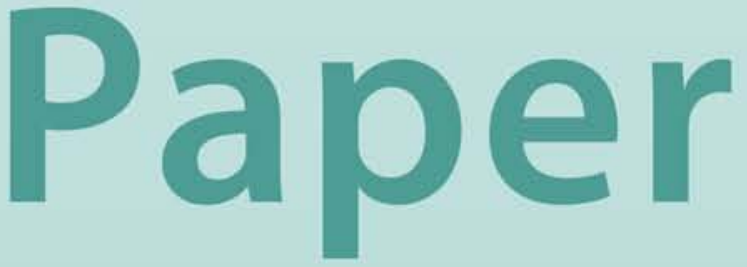


Should Unconventional Balance Sheet Policies

be Added to the Central Bank Toolkit?

A Review of the Experience So Far

Mark Stone, Kenji Fujita, and Kotaro Ishi 


\title{
IMF Working Paper
}

Monetary and Capital Markets Department

\section{Should Unconventional Balance Sheet Policies be Added to the Central Bank Toolkit? A Review of the Experience So Far}

\author{
Prepared by Mark Stone, Kenji Fujita, and Kotaro Ishi ${ }^{1}$
}

Authorized for distribution by Karl Habermeier

June 2011

\begin{abstract}
What is the case for adding the unconventional balance sheet policies used by major central banks since 2007 to the standard policy toolkit? The record so far suggests that the new liquidity providing policies in support of financial stability generally warrant inclusion. As the balance sheet policies aimed at macroeconomic stability were used only by a small number of highly credible central banks facing a lower bound constraint on conventional interest rate policy, they are not relevant for most central banks or states of the world. Best practices of these policies are documented in this paper.
\end{abstract}

JEL Classification Numbers: E52, E58, F42

Keywords: Monetary policy, crisis policies, liquidity support.

Author’s E-Mail Address: mstone@imf.org; kfujita@imf.org; and kishi@imf.org

This Working Paper should not be reported as representing the views of the IMF. The views expressed in this Working Paper are those of the author(s) and do not necessarily represent those of the IMF or IMF policy. Working Papers describe research in progress by the author(s) and are published to elicit comments and to further debate.

\footnotetext{
${ }^{1}$ Helpful comments were provided by Simon Gray, Karl Habermeier, Christopher Towe and participants at a Monetary and Capital Markets Department seminar at the IMF, and by Eugenio Gaiotti and other participants at an European Central Bank Workshop. Simon Townsend provided excellent research assistance.
} 


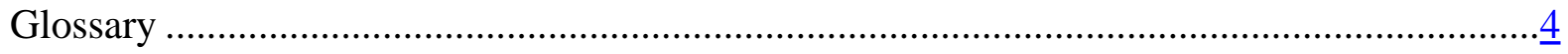

I. Introduction and Summary …………………………...................................................

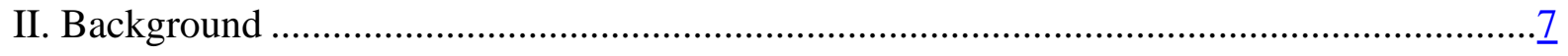

III. The Experience with Unconventional Central Bank Balance Sheet Policies .......................10

A. Financial Stability Balance Sheet Policies......................................................12

B. Macroeconomic Stability Policies.........................................................................

IV. Adding Balance Sheet Policies to the Standard Central Bank Toolkit.................................26

A. Financial Stability Balance Sheet Policies..............................................................26

B. Macroeconomic Stability Balance Sheet Policies .......................................................29

V. Implementing Balance Sheet Policies ..................................................................................

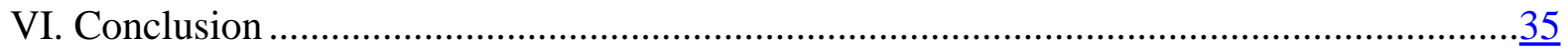

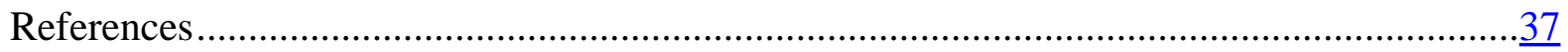

Tables

1. Unconventional Central Bank Balance Sheet Policies ............................................................

2. Examples of Central Bank Unconventional Balance Sheet Policies ......................................12

3. Terms of Funding Market and Credit Market Liquidity Support Operations.........................16

4. Credit Risk Exposures Associated with Credit Market Liquidity Support............................17

Figures

1. Accumulated Balance Sheet Changes, Major Central Banks .................................................46

2. Maturing and Collateral Composition of Liquidity Support, Reserve

Bank of Australia .........................................................................................................47

3. Liquidity Support to Domestic Funding Markets ..............................................................47

4. Liquidity Support to Domestic Credit Markets ………………………………………...... 48

5. Maximum TED Spread and Maximum Domestic Market Support ....................................... 48

6. The Maximum Amount of Bilateral Swap with the Fed......................................................49

7. Selected Central Banks, Terms of Foreign Exchange Liquidity Provision Sourced from the Federal Reserve ..........................................................................................

8. Selected Countries, Policy Interest Rates .......................................................................

9. Bond Purchases and Policy Interest Rate...........................................................................

10. Holders of Public Securities....................................................................................

11. Holders of Public Securities, Flows ..............................................................................

12. Exchange Rate, Policy Interest Rate, and Foreign Exchange Purchases ..............................53

13. Changes of Libor-OIS Spreads from the Eent Day ………………………………........

14. Stylized Balance Sheet-Central Bank, Government, and Consolidated Sovereign ..........59

15. Estimated Maturity of Consolidated Sovereign Debt ..........................................................61 
Boxes

1. Challenges and Risks Posed by Liquidity Provision ....................................................28

2. Challenges and Risks from Central Bank Bond Purchases and Credit Provision .................

3. Best Practices of Central Bank Balance Sheet Policies ..................................................

Appendices

I. Central Bank Liquidity Support for Individual Financial Institutions During the Recent Crisis .$\underline{54}$

II. Unraveling Financial Risks of Bond Purchase...................................................... $\frac{56}{62}$

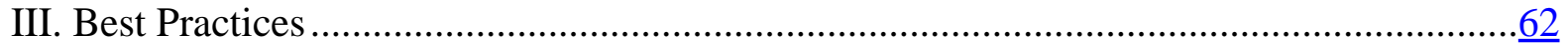




\section{GLOSSARY}

ABS

AE

AMLF

APF

BoC

$\mathrm{BoE}$

BoI

BoJ

CE

$\mathrm{CHF}$

CPFF

ECB

ETF

Fed

FOMC

FX

GSE

LIBOR

LTCM

LTRO

MBS

OIS

PRA

QE

RBA

REIT

SNB

TAF

TALF

TED

TSLF

VAR

Asset backed securities

Advanced economies

Asset Backed Commercial Paper Money Market Mutual Fund Liquidity Facility

Asset purchasing facility

Bank of Canada

Bank of England

Bank of Israel

Bank of Japan

Credit easing

Swiss franc

Commercial paper funding facility

European Central Bank

Exchange traded funds

Federal Reserve

Federal Open Market Committee

Foreign Exchange

Government-sponsored enterprise

London Interbank Offer Rate

Long Term Capital Management

Long-term refinancing operations

Mortgage backed securities

Overnight indexed swap

Purchase and Resale Agreements

Quantitative easing

Reserve Bank of Australia

Real Estate Investment Trust

Swiss National Bank

Term Auction Facility

Term Auction Lending Facility

Treasury Bill Rates

Term Securities Lending Facility

Value at risk 


\section{INTRODUCTION AND SUMMARY}

1. The shift of major central banks to balance sheet policies beginning in 2007 reversed the late $20^{\text {th }}$ century trend toward a narrow and well-defined central bank policy scope. ${ }^{2}$ Central banking began at the end of the $17^{\text {th }}$ century to help governments issue debt and thereafter central banks took on a succession of broader policy responsibilities from issuer of reserve money to lender of last resort, and in some cases supervision. By the middle of the $20^{\text {th }}$ century, the remit of many central banks was extended into a range of quasi-fiscal activities. The problems posed by fiscal mission creep and related high inflation led to a narrowing and clarification of the policy role of central banks during the "golden age" of central banking from around 1990 to 2008 (Gerlach and others, 2009).

2. The recent crisis necessitated a return to a more expansive central bank reach. Many central banks provided massive amounts of both domestic and foreign exchange liquidity to prevent stress in key markets from hitting the real economy. The lower bound constraint on monetary policy interest rates forced several major central banks to switch to purchases of longterm public bonds and even foreign exchange to further ease their policy stance. These policies broke from the conventional (pre-crisis) framework and brought central banks back into overlap with fiscal and other policies.

3. Central banks around the world are today deciding whether, and, if so, how, these unconventional policies should be added to their toolkit. This paper documents what central banks did, reviews the burgeoning theoretical and empirical work and discusses whether and how unconventional balance sheet policies should be added to the toolkit. Enough time has passed to provide sufficient empirical evidence to form at least preliminary views on the effectiveness of most balance sheet policies. The costs and risks of balance sheet policies, however, stretch out over the longer term. Thus, more time will be needed for a definitive judgment.

4. The experience of the large advanced and emerging market economy (major) central banks that use a short-term interest rate as the operating target of monetary policy is covered here. However, given the widespread interest in these policies, the assessment of the paper is meant to be relevant to a wide range of central banks - not just those that recently employed unconventional balance sheet measures. The use of unconventional policies by major central banks since 2007 is described in some detail and the burgeoning literature on them is reviewed. The positive assessment of which policies may warrant addition to the toolkit is based on consideration of their relevance for a given central bank, effectiveness against the costs and risks, and whether the central bank is best suited to implement the policy compared to other public entities. Finally, a set of best practices is offered.

\footnotetext{
${ }^{2}$ For histories of central banking, see Goodhart (1988), De Kock (1974), and Bagehot (1878).
} 
5. In summary, most of the unconventional balance sheet policies used by the major central banks appear to have been effective, albeit to varying degrees. Against these apparent benefits must be weighed the risks posed by the overlaps of these policies with other policy spheres, the need for an exit strategy, and risks to the balance sheet.

6. More specifically, the policies used to support financial stability broadly warrant inclusion for use to counter systemic financial stress (Table 1). Liquidity provision to funding and credit markets and the provision of foreign exchange liquidity to local markets reduced the impact of financial stress on the real economy, and have for the most part been wound down without disruption. Further, the systemic importance of financial markets can be, if anything, expected to increase, and thus they warrant a broad set of liquidity provision tools. Some of the elements of the broadening of liquidity provision put in place during the crisis could be kept on permanently, depending on what the new financial landscape looks like. Inclusion of liquidity provision policies to the toolkit should be complemented by fully effective regulation and supervision to mitigate against the moral hazard problem.

Table 1. Unconventional Central Bank Balance Sheet Policies

\begin{tabular}{|c|c|c|}
\hline Objective & Policy & Inclusion in the toolkit \\
\hline \multirow[t]{2}{*}{$\begin{array}{l}\text { Financial } \\
\text { stability }\end{array}$} & $\begin{array}{l}\text { Liquidity provision to funding } \\
\text { and credit markets }\end{array}$ & $\begin{array}{l}\text { Appropriate when liquidity stress spilling over into real } \\
\text { economy but with safeguards and coordination }\end{array}$ \\
\hline & $\begin{array}{l}\text { Foreign exchange liquidity } \\
\text { provision to local markets }\end{array}$ & $\begin{array}{l}\text { Appropriate when foreign exchange liquidity stress } \\
\text { spilling over into real economy but with safeguards and } \\
\text { coordination }\end{array}$ \\
\hline \multirow[t]{3}{*}{$\begin{array}{l}\text { Macroeconomic } \\
\text { stability }\end{array}$} & Bond purchases & $\begin{array}{l}\text { Effective for highly credible central banks to a degree } \\
\text { when the policy rate is at the lower bound but there are } \\
\text { risks and policy overlaps }\end{array}$ \\
\hline & $\begin{array}{l}\text { Large-scale foreign exchange } \\
\text { intervention }\end{array}$ & $\begin{array}{l}\text { Effective for highly credible central banks in stemming } \\
\text { appreciation in the short-run but also poses important } \\
\text { policy, balance sheet, and multilateral risks }\end{array}$ \\
\hline & $\begin{array}{l}\text { Credit provision to the private } \\
\text { sector }\end{array}$ & $\begin{array}{l}\text { Weak case to be done by the central bank vis-à-vis the } \\
\text { government in all but the most exceptional circumstances }\end{array}$ \\
\hline
\end{tabular}

7. The policy relevance of macroeconomic stability balance sheet measures is limited to the highly credible central bank facing a lower bound constraint on conventional interest rate policy. Purchases of long-term public bonds are an option for these central banks when the interest rate is constrained by the lower bound, but their effectiveness is probably limited and their considerable overlap with fiscal policies and exiting can pose problems. Large-scale foreign exchange intervention may stem appreciation, at least in the short run, but they can also impose important costs and risks, including in the multilateral sphere. The case for central bank 
provision of credit to the private sector - which has been used only on a limited basis - is weak for any central bank except in the most exceptional circumstances, since this is distortionary and inherently fiscal.

8. Adding balance sheet policies to the toolkit raises tricky implementation issues. They must be fit into the broad macroeconomic policy framework with respect to coordination and implementation. A set of best practices is proposed in this paper drawing from conventional policies and actual implementation during the crisis to enhance the effectiveness of unconventional policies and minimize the risks. Choosing the right degree of transparency and balancing effectiveness against distortions are perhaps the most difficult challenges here.

9. Much work lies ahead to fold balance sheet policies into the new post-crisis economic policy frameworks. As a result of the crisis, the full range of economic policies is today in flux. The new central bank market liquidity support policies must be integrated into revised and more far-reaching crisis management frameworks. The macroeconomic stability policies will eventually need to be wound down and the special circumstances under which they could be used in the future established.

10. The addition of balance sheet policies to the toolkit during the post-crisis period of financial reform and heavy fiscal burdens warrants a note of caution. Central banks and governments are faced with a host of post-crisis challenges, including fiscal consolidation. The misuse of central bank policies could potentially contribute to a downside destabilizing dynamic of fiscal dominance and a loss of central bank independence. Authorities will need to meet head on the post-crisis challenges to avoid this downside scenario and preserve the historically large measure of credibility gained by central banks during the pre-crisis golden age.

11. This paper is organized as follows. The next section lays out the comparative policy advantages of central banks and reviews the conventional pre-2007 policy frameworks. Section III documents and discusses in some detail the unconventional central bank balance sheet policies utilized since 2007. Section IV discusses which of these policies may warrant inclusion in the toolkit. The implementation of balance sheet policies is elaborated in section $\mathrm{V}$, and section VI briefly concludes. Three appendices describe liquidity support for individual financial institutions during the crisis, detail the financial risks posed by bond purchases and document and discuss the best practices of central banks.

\section{BACKGROUND}

12. This section sets the stage by discussing what makes central bank policies work generally and describing the conventional pre-2007 policy framework. Consideration of what gives central bank policies traction facilitates analysis of how they were able to widen the scope of their policies and for judging which unconventional policies could be added to the toolkit. A review of the pre-crisis monetary policy framework provides a point of departure for describing unconventional policies and informs how they can fit into the post-crisis policy framework. 


\section{What makes central bank policies work}

\section{The power of central banks to influence the economy arises from a combination of their legal mandate, functional responsibilities, and expertise:}

- $\quad$ Legal mandate for policy objectives - Most major central banks have a legal mandate for some form of price stability and a few are charged with other macroeconomic objectives. An explicit or implicit mandate for financial stability (often cast in terms of the payments system) is also common.

- $\quad$ Reserve money creation - Central banks have the exclusive right to issue reserve money. This allows them to provide domestic liquidity during times of stress. Reserve money creation also facilitates the control of short-term interbank market rates.

- $\quad$ Market operations role-Central banks implement monetary policy by regularly intervening in domestic and foreign exchange markets. This longstanding role has given them a unique capacity to monitor and analyze market developments.

- $\quad$ Foreign exchange policy role-In almost all economies, central banks implement foreign exchange rate policies, whether or not they actually shape them.

- $\quad$ Conditional access to public sector resources-Central banks usually have de facto access to fiscal resources sufficient to allow them to effectively implement their policies. This fiscal autonomy can allow them to operate quickly and flexibly. ${ }^{3}$

- Information and analytical advantages - The above special powers of central banks, as well as their economies of scale in data collection and analysis, and role as government advisor can provide them with an information and analytical advantage over the markets and the public (Romer and Romer, 2000). Major central banks tend to be trusted as a credible source of information not just on their own policy preferences but also on the state of the economy. These advantages, together with their policy responsibilities, make it worthwhile for the markets and the public to pay careful attention to the views of the central bank on monetary and financial conditions.

\section{Conventional pre-2007 policies}

14. During the "great moderation," the central banks of almost all advanced economies and of many large emerging market economies arrived at a broadly similar monetary framework in support of macroeconomic stability. Almost all came to target inflation,

\footnotetext{
${ }^{3}$ The de jure obligation of governments to recapitalize central banks varies considerably (Lonnberg and Stella, 2008).
} 
whether explicitly or implicitly (Stone and Bhundia, 2004). Monetary policy became more forward-looking and aimed at influencing inflation expectations, which can be considered as an intermediate objective (Svensson, 1997). Major central banks gained independence in monetary policy, and central bank laws often specify independence in monetary operations. Transparency and accountability were also enhanced, in part to enhance monetary policy effectiveness (Roger and Stone, 2005) but also to preserve legitimacy of the central bank's independent status in a democratic framework. There is some consensus that at least some of the decline in inflation and output variability that marked the "great moderation" of the 1990s and 2000s can in part be attributed to the consensus regarding key aspects of monetary policy frameworks (Bernanke, 2004; Gali and Gambetti, 2009).

\section{The conventional monetary policy framework employs two main instruments in support of macroeconomic stability:}

- $\quad$ Interest rate policy - Conventional monetary policy is implemented with a single short-term policy instrument (BIS, 2009a). Over time, a buildup of policy credibility has increased the importance of the "signaling channel." Markets can bring about an announced interest rate change without any actual injection or withdrawal of liquidity by the central banks (Disyatat, 2008; Friedman and Kuttner, 2010). Further, interest rate policy influences the shape of the yield curve (Eggertsson and Woodford, 2003).

- $\quad$ Foreign exchange intervention-Some central banks, mostly of more open emerging market economies, intervene in foreign exchange markets mainly to smooth short-run exchange rate shocks or restore exchange rate equilibrium (Stone and others, 2009a). These operations are typically sterilized so that they do not alter the targeted interest rate.

16. Most major central banks adhere to certain monetary operations “principles.” These reflect the central bank's commitments to maximizing the effectiveness of monetary policy, safeguards to protect their independence in monetary policy, and delineate monetary policy from fiscal policy:

- $\quad$ Market and counterparty neutrality — interest rates are to influence aggregate demand and inflation, rather than the distribution of resources (a fiscal policy function).

- $\quad$ Flexibility — monetary operations are designed to be flexible so as to smooth liquidity shocks and ensure effective transmission of monetary policy.

- $\quad$ Balance sheet protection—risk management ensures that central bank independence is not threatened by a need for fiscal resources.

Of course, differences in financial systems mean that the parameters (range of eligible collateral and counterparties) of monetary operations vary considerably. 
17. Prior to the recent crisis, measures in support of systemic financial stability were relatively rare (IMF, 2010c). From the 1990s through the late 2000s, financial systems were stable in advanced economies compared to earlier periods (Laeven and Valencia, 2010). Variations in liquidity provision to financial institutions were usually small in scale compared to reserve money and were sterilized to preserve the monetary stance and overall liquidity conditions. On a few occasions, central banks undertook short-lived liquidity injections to maintain stable systemic liquidity conditions such as during the Long Term Capital Managmenet (LTCM) crisis, the Y2K transition, and after September 11, 2001. Japan in the late 1990s and early 2000s, when the Bank of Japan (BoJ) launched a wide variety of balance sheet measures, was an exception.

\section{The Experience With Unconventional Central Bank Balance Sheet Policies}

\section{Consideration of the wide array of unconventional central bank balance sheet} policies employed during the crisis requires some sort of taxonomy. A consensus about definitions of unconventional measures has yet to be reached reflecting the few years in which they have been in place and the different approaches taken by central banks. ${ }^{4}$

\section{In this paper, balance sheet policies are divided first according to whether they are} aimed at financial or macroeconomic stability. In almost all respects, these two objectives are quite different with respect to mandate, institutional arrangements and accountability. The financial stability role of central banks usually involves mitigation policies-for example, market and bank monitoring or in some cases regulation and supervision — as well as crisis management. The balance sheet measures considered here are for the purpose of crisis management (although, as discussed later, crisis management and mitigation policies should be coordinated).

\section{Unconventional balance sheet policies are broken down further by how they}

transmit. Financial stability policies are divided into domestic and foreign exchange liquidity provision to local markets since these transmit differently and because the central bank has much more control over the liquidity of domestic instruments vis-à-vis foreign exchange. The three macroeconomic stability policies are intended to stimulate the economy in different ways. Bond purchases transmit mainly via long-term yields, credit provision by boosting spending of targeted

\footnotetext{
${ }^{4}$ Several other taxonomies have been employed. Balance sheet policies have been divided into those that increase the size of the balance sheet and those that alter its composition (e.g., Bernanke and others, 2004). Balance sheet policies have also commonly been sorted into quantitative easing (QE), usually referring the purchase of long-term securities by the central bank, and credit easing (CE), or support for credit markets (cf Bernanke, 2009a and Lenza and others, 2010). However, these terms are not used consistently. QE bond purchases can be for the financial stability objective of boosting secondary market liquidity or for the macroeconomic goal of reducing long-term interest rates. Similarly, CE has been used to refer to support for financial stability objectives (e.g., to boost liquidity in an important secondary credit market) and to more direct support to borrowers (e.g., central bank lending to corporations). Borio and Disyatat (2009) employ another taxonomy of exchange rate policy, quasi-debt management policy, credit policy, and bank reserves policy. Finally, the taxonomy employed here may not square with how central banks described their own balance sheet policies.
} 
sectors, while large-scale foreign exchange intervention works mainly through the exchange rate channel. Examples employed by the major central banks have taken since 2007 are shown in Table 2.

21. This paper seems to be the first to provide a comprehensive review of the unconventional balance sheet measures used by major central banks since 2007. A number of central banks have issued studies of their own measures and theoretical and empirical research is well underway as documented in this paper. The few cross-country studies have focused on either the largest of the advanced economies (Lenza and others, 2010; Borio and Disyatat, 2009; Klyuev and others, 2009) or on emerging economies (Ishi and others, 2009; Moreno, 2011).

\section{The large advanced economies depended the most on unconventional policies}

\section{The large advanced economy central banks leaned heavily on unconventional} balance sheet policies. The Federal Reserve (Fed), Bank of England (BoE) and the European Central Bank (ECB) utilized these policies the most, reflecting the complexity of their financial systems and the concomitant degree of stress (Figure 1) and the related lower bound constraint on policy interest rates. The smaller advanced economies generally used unconventional measures less, reflecting their more stable bank-based financial systems. Exceptions here are Israel and Switzerland which undertook large foreign exchange purchases, as well as Sweden.

23. For emerging market economies, the relatively limited provision of liquidity to domestic financial markets was due to the lower degree of systemic stress. Many emerging market economies did provide large foreign exchange liquidity support. The policy interest rate in only a few emerging market economies fell to near a lower policy bound, reflecting their higher and more volatile inflation and real interest rates to compensate for the extra risk faced by investor, including of a sudden stop. Thus, they did not face the exceptional circumstance of interest rates constrained by the lower bound and had no need to resort to macroeconomic stability balance sheet policies.

\section{For emerging market economies, the relatively limited provision of liquidity to} domestic financial markets was due to the lower degree of systemic stress. Many emerging market economies did provide large foreign exchange liquidity support. The policy interest rate in only a few emerging market economies fell to near a lower policy bound, reflecting their higher and more volatile inflation and real interest rates to compensate for the extra risk faced by investor, including of a sudden stop. Thus, they did not face the exceptional circumstance of interest rates constrained by the lower bound and had no need to resort to macroeconomic stability balance sheet policies.

\section{Policy objectives shifted in early 2009}

25. The focus of unconventional balance sheet policies shifted from an exclusive focus on financial stability to include macroeconomic concerns after early 2009 (Figure 1). The provision of sterilized liquidity to stressed domestic markets and on a limited basis to local 
insolvency is best handled by the government because the mobilization of real resources for recapitalization must involve the exercise of fiscal authority. The significant amounts of conventional liquidity support for individual financial institutions provided by several advanced economy central banks is not a focus of this paper; this support is described in Appendix I.

\section{Liquidity support for domestic funding and credit markets ${ }^{5}$}

\section{This measure aims to restore stable conditions in systemically important markets} deemed far away enough from equilibrium to adversely affect the real economy. Usually, market liquidity support is expected to lower the targeted market interest rate and restore volumes. Reserve issuance is a prerequisite for large-scale central bank support to domestic markets. Central bank knowledge of markets and access to supervisory information allows them to identify market stress and central bank's detailed knowledge of the economy allows them to determine when such stress can become systemic. In addition, information and analytical advantages of a central bank can allow it to boost confidence sapped by systemic instability. Funding support to domestic markets overlaps with monetary policy in the sense that it can be at least partially motivated by a need to unfreeze monetary transmission.

\section{In the summer of 2007, central banks began to modify existing operations to} alleviate stress in funding markets (Chailloux and others, 2008). Duration was shifted from counterparties to central banks by extending the maturity of liquidity provision, the frequency of operations was stepped up, collateral standards were in many cases broadened, and in a few cases the number of counterparties was increased (Figure 2). In most cases, the maturity of liquidity provision was extended by lengthening the tenor of operations. ${ }^{6}$ Central banks drew a clear distinction between the monetary policy stance and the provision of liquidity to financial institutions (cf Stark, 2008) and these measures were sterilized.

\section{In September 2008, large advanced economy central banks expanded liquidity} support to funding markets and began to provide extensive support to credit markets (Figure 3). Examples of systemically important markets included commercial paper, corporate bond, mortgage backed securities, and asset backed securities. ${ }^{7}$ Bank reserves and central bank

\footnotetext{
5 The term "funding markets" refers here to short-term money markets in which financial institutions trade bank reserves (e.g., interbank markets, repo markets), while the term “credit markets” denotes financial markets in which not only financial institutions but also non-financial enterprises issue debt instruments, such as commercial paper, corporate bonds, and asset backed securities.

${ }^{6}$ For example, the Fed introduced its 1-month term auction facility (TAF) in December 2007 and extended the tenor to three-months in August 2008, while the maturity of its repo operations in normal time was two-week at maximum. The ECB, which had regularly conducted 1-week and 3-month refinancing operations, extended the maturity to 6 months in April 2008 and to 12 months in June 2009.

7 The MBS/GSE debt purchases by the Fed initially announced on November 25, 2008 (about three weeks before the policy rate was reduced to effective zero) can be judged as intended to ameliorate the stress in MBS / GSE debt markets for financial stability purposes.
} 
balance sheet sizes rose sharply (Figure 4). The decision to no longer sterilize market liquidity support after September 2008 seems to have been driven by the perceived need to err on the side of providing liquidity to the system and as a way of signaling central bank commitment to addressing the acute problems in the face of plummeting confidence. By mid-2010, most central banks had stopped purchases of credit instruments for financial stability purposes. In May 2010, the ECB initiated a Security Market Programme to address the malfunctioning of securities markets and to restore monetary policy transmission.

30. Market liquidity providing policies varied considerably across advanced economy central banks. The very large differences in the magnitude and modalities of liquidity injection across central banks seem to reflect varied market structures and degrees of financial stress, as gauged by the spread between the 90-day LIBOR and the treasury bill rates (TED) (Figure 5) (Lenza and others, 2010). The different responses can also be attributed to the complexity of financial markets and to variations in pre-crisis monetary operation frameworks across economies. For instance, the central banks that conducted open market operations with a broader range of counterparties and against a wider variety of collateral (ECB, BoJ) before the crisis introduced fewer changes in these respects than other central banks.

31. The domestic liquidity easing measures of emerging market economy central banks were on a smaller scale (Ishi and others, 2009; Moreno, 2011). They cut reserve requirements — which some use on a regular basis—expanded eligible reserve assets and some also widened the list of eligible collateral for monetary operations, broadened counterparties, and extended the maturity of liquidity providing operations. In a few cases, the government was actively involved in providing liquidity. The use of domestic liquidity easing measures was positively related to the size of the economy, possibly reflecting the associated size of the financial sector, and negatively related to international reserves, which may have mitigated the impact of external liquidity shocks (Ishi and others, 2009).

\section{Liquidity support tended to be transparent and stricter for credit markets}

\section{Central banks often used spreads or interest rates of funding markets as de facto} operating targets. Some sort of operating target is needed for communication and accountability. Spreads of London Interbank Offer Rate (LIBOR) over overnight indexed swap (OIS) or treasuries was often used as a de facto operating target. In some cases, outstanding market amounts were cited as "operating indicators" (e.g., commercial paper volume) while in other cases (e.g., unsecured money markets in some countries) data are not available on market quantities.

33. Liquidity providing operations tended to be relatively transparent. In most cases, the objectives, instruments implementation of liquidity support were transparent and in some cases heavily publicized, as central banks aimed to signal their commitment to improve market and overall confidence. 
34. The terms of credit market support was generally stricter compared to that for funding markets. Central banks generally charged higher interest rates for support to credit markets to speed exiting and possibly to cover credit risk (Table 3 ). ${ }^{8}$ For credit markets, purchase prices were often set at a level attractive only under stressed conditions to reduce the risks that markets become overly dependent on central banks’ operations. Further, most central banks purchased only investment grade securities and required larger haircuts for lower credit quality collateral.

35. Exit strategies for credit market support were more explicit compared to funding market operations (Table 3). Credit market support was provided with an explicit termination date, with the termination usually conditioned on improved market liquidity.

36. Loss sharing arrangements between the central bank and government were agreed in some countries. For instance, the BoE has been fully indemnified by the government from loss arising from purchases of corporate bonds and commercial papers. The Fed agreed with the government that the first loss amounting to 10 billion US\$ from its term auction lending facility (TALF) program shall be burdened by the government. The 5 billion euro increase in the subscribed capital of the ECB at end-2010 was largely seen by markets as a means to share possible losses arising from the ECB's liquidity support measures to funding and government bond markets.

\section{Liquidity support reduced market stress at limited costs but also supplanted markets}

\section{The empirical literature, with few exceptions, concludes that central bank market} liquidity provision reduced funding costs. Taylor and Williams (2008) argued that the Federal Reserve's TAF did not reduce premia because these reflected credit risk. In contrast, McAndrews and others (2008) and Wu (2010) found that the TAF decreased premiums during end-2007 to mid-2008. Artuç and Demiralp (2009) found that the Fed's primary credit lending facility stabilized the federal funds market. Reserve Bank of Australia (2009) concluded that their easing measures helped decrease the spreads of money market rates over OIS rates during mid-2007 to early 2009. Baba and others (2006) assessed that the massive injection of liquidity by the Bank of Japan during 2001-2006 reduced the funding costs of financial institutions. Aït-Sahalia (2009) also found that liquidity supports by central banks since the summer of 2007 contributed to stabilizing interbank markets in large advanced economies. Fleming and others (2010) found that the Federal Reserve operations to provide treasury securities against less liquid assets such as agency and mortgage-backed securities (TSLF) reduced repo rates against these securities in comparison with repo rates against treasury securities. Hirose and Ohyama (2010) concluded that market operations by the Bank of Japan stabilized commercial paper markets.

\footnotetext{
${ }^{8}$ According to Bernanke (2010a), "Generally, the Federal Reserve lent at rates above the 'normal' rate for the market but lower than the rate prevailing in distressed and illiquid markets.”
} 
Table 3. Terms of Funding Market and Credit Market Liquidity Support Operations

\begin{tabular}{|c|c|c|c|c|}
\hline & & Measures & Penal pricing & $\begin{array}{c}\text { Explicit } \\
\text { termination date }\end{array}$ \\
\hline \multirow{6}{*}{$\begin{array}{l}\text { Liquidity support } \\
\text { to funding } \\
\text { markets }\end{array}$} & Fed: & Term Auction Facility & No & No \\
\hline & ECB: & Fixed-rate full allotment LTRO & No & No \\
\hline & BoE: & Active use of LTRO & No & No \\
\hline & \multirow{2}{*}{ BoC: } & Introduction and active use of Term & No & No \\
\hline & & PRA & No & No \\
\hline & RBA: & Active use of term repo operations & & \\
\hline \multirow{7}{*}{$\begin{array}{l}\text { Liquidity support } \\
\text { to credit markets }\end{array}$} & \multirow[t]{3}{*}{ Fed: } & Commercial Paper Funding Facility & Yes & Yes \\
\hline & & $\begin{array}{l}\text { Asset-Backed Commercial Paper } \\
\text { MMMF Liquidity Facility }\end{array}$ & Yes & Yes \\
\hline & & Term ABS Loan Facility & Yes & Yes \\
\hline & ECB: & Covered bonds purchase & No & Yes \\
\hline & BoE: & $\begin{array}{l}\text { APF (corporate bonds / commercial } \\
\text { paper) }\end{array}$ & Yes & Yes \\
\hline & \multicolumn{2}{|c|}{$\begin{array}{l}\text { BoJSpecial Funds-Supplying Operations to } \\
\text { Facilitate Corporate Financing }\end{array}$} & No & Yes \\
\hline & & $\begin{array}{l}\text { Purchase of corporate bonds and } \\
\text { CPS }\end{array}$ & Yes & Yes \\
\hline
\end{tabular}

Sources: Central bank websites and press reports.

38. Assessing the impact of liquidity provision on credit conditions is more difficult. Adrian and others (2010) note that the Fed's Commercial Paper Funding Facility made up over 20 percent at its peak in late 2008 of the total outstanding amount of commercial papers. Then the use of the facility declined as the spread of commercial paper rates dropped and the outstanding amount in the market stopped decreasing. The Fed also reported that the issuance of consumer asset-backed securities was "solid" during the second quarter of 2010, as the use of TALF declined toward its expiration date at end-June. Fahr and others (2010) and Giannone and others (2011) employ (value at risk) VAR models focusing on interest rates spreads to conclude that the ECB's enhanced credit support program facilitated conventional monetary transmission and credit flows.

39. At the same time, central bank liquidity support likely contributed to a long-lasting contraction of some funding markets (IMF, 2010d). Of course, this may also be driven by what can now be seen as inherent weaknesses in some of these markets, for example related to 
the shadow banking sector. Information is not available on the losses of market infrastructure or distortions arising from market support.

40. Central banks have unwound some, but not all, of the expansions in eligible collateral and changes in counterparty arrangements made during the crisis (IMF, 2010a). While the Fed and the Bank of Canada (BoC) have been restoring the pre-crisis arrangements for open market operations counterparties and collateral, the Reserve Bank of Australia maintains the extended collateral framework. The BoJ also maintains an expanded collateral list for some foreign government bonds in the context of so-called cross-border collateral and has been running down the active use of private instruments. Meanwhile, the BoE has proposed a wider range of collateral to provide liquidity insurance to the banking system.

Table 4. Credit Risk Exposures Associated with Credit Market Liquidity Support (In percent of GDP)

\begin{tabular}{|c|c|c|c|c|}
\hline & Measures & $\begin{array}{l}\text { Minimum rating } \\
\text { requirement }\end{array}$ & $\begin{array}{l}\text { Maximum } \\
\text { exposure after } \\
\text { July } 2007\end{array}$ & $\begin{array}{c}\text { Exposure as } \\
\text { of March } \\
2011\end{array}$ \\
\hline \multirow[t]{3}{*}{ Fed: } & Commercial Paper Funding Facility & $a-1$ & 2.3 & - \\
\hline & $\begin{array}{l}\text { Asset-Backed Commercial Paper MMMF } \\
\text { Liquidity Facility }\end{array}$ & $a-1$ & 0.7 & - \\
\hline & Term ABS Loan Facility & AAA & 0.3 & 0.1 \\
\hline ECB: & Covered bonds purchase & $A A$ & 0.6 & 0.6 \\
\hline BoE: & $\begin{array}{l}\text { APF (corporate bonds / commercial } \\
\text { paper) }\end{array}$ & $\mathrm{BBB} / \mathrm{a}-3$ & 0.2 & 0.1 \\
\hline BoJ: & $\begin{array}{l}\text { Purchase of corporate bonds and } \\
\text { commercial paper }\end{array}$ & A / a-1 & 0.3 & - \\
\hline
\end{tabular}

41. Central bank losses on liquidity providing operations seem to have been minimal. Liquidity providing operations have been wound down for the most part and have posed relatively limited credit and market risks for central banks. Reflecting the strict terms of support, no financial losses have materialized from those unconventional balance sheet policies as of end-August 2010, though several facilities continue holding legacy assets (Table 4).

\section{Liquidity support for local foreign exchange funding markets}

42. Liquidity support for foreign exchange funding markets aims to alleviate stress that can carry over to the real sector. Foreign exchange funding support follows from the central bank's foreign exchange policy role as well as its market operations role and information advantages. Foreign exchange liquidity provision can be financed by a willing reserve currency 
central bank. This measure is distinct from standard foreign exchange intervention aimed at smoothing short-term exchange rate shocks. ${ }^{9}$

43. Central banks provided a considerable amount of foreign exchange liquidity mostly in U.S. dollars. ${ }^{10}$ The ECB and SNB started providing U.S. dollar liquidity in late 2007 to prevent the illiquidity of U.S. dollar funding markets from posing systemic risks. Dollar provision by central banks to local foreign exchange markets sharply increased toward the end-2008 and temporarily accounted for large shares of advanced economy central bank balance sheets. In addition, other several reserve currencies-euro and swiss franc-were also provided through foreign central banks.

\section{Many emerging market economy central banks eased foreign exchange liquidity} conditions using a wide array of measures (Ishi and others, 2009; Moreno, 2011). ${ }^{11}$ They relaxed the terms of existing foreign exchange facilities, extended maturities of foreign exchange swaps or introduced new facilities providing foreign exchange repos, loans. ${ }^{12}{ }^{13}$ Many opened foreign exchange selling auctions and eased foreign exchange liquidity or borrowing limits. Furthermore, some central banks lowered the required reserve ratio for bank foreign currency liabilities. Many provided foreign exchange liquidity at penalty interest rates. Empirical evidence suggests that it was the larger emerging market economy with more developed financial sectors, flexible exchange rate regimes and lower foreign exchange reserves that utilized foreign exchange liquidity easing measures (Ishi and others, 2009).

\section{Cross-central bank swaps in support of foreign exchange liquidity provision was a} novel aspect of the crisis (Figure 6). These are bilateral agreements between central banks that in essence involve the provision of liquidity from a central bank whose currency was in demand to another central bank for distribution by it to local institutions. These arrangements accounted

\footnotetext{
${ }^{9}$ In making this distinction, Calvo (2006) takes the view that foreign exchange liquidity support follows from an information advantage of the central bank which allows it to identify risks, which give reason to circumvent a dysfunctional foreign exchange market and provide liquidity to systemically important institutions. In late 2008, foreign exchange markets in a number of countries ceased to function because banks were hoarding foreign exchange (Baba and packer, 2009).

${ }^{10}$ Foreign exchange liquidity support is more difficult to measure compared to other balance sheet policies because many central banks do not report foreign exchange swap data and don't report foreign exchange sales aimed at liquidity easing.

${ }^{11}$ The theoretical model of Martins and Salles (2010) has segmented domestic and foreign exchange markets makes central bank foreign exchange liquidity provision out of foreign reserves effective.

${ }^{12}$ Foreign exchange swaps (the sale of foreign exchange with a commitment to buy back from the counterparty at a specified date and exchange rate) may be preferable to intervention in the spot market because the latter can be interpreted as meant to influence the exchange rate.

${ }^{13}$ The central bank of Brazil provided collateralized US\$ financing via auction to financial institutions, who on-lent to exporters, and targeted Brazilian corporations with US\$ loan payments falling due over a pre-specified period.
} 
for most of the foreign exchange liquidity provision. Swaps can increase the availability of foreign exchange liquidity to local institutions and buttress market confidence. The Fed established dollar swap arrangements with fourteen central banks and the ECB and the Swiss National Bank (SNB) also supplied liquidity in their currencies.

\section{Operational design reflected global market conditions and exit strategies}

\section{The terms of central bank local dollar liquidity provision sourced from the Fed} changed with the acceleration of global stress in September. Early in the crisis, when stress was concentrated in a few markets, the Fed swap arrangements were limited in quantity and the liquidity-receiving central banks distributed dollars locally at close to the rate in U.S., as gauged by the TAF interest rate (Figure 7). In September 2008, the Fed shifted to providing unlimited dollar access to selected countries. Thereafter, liquidity-receiving central banks charged a premium, presumably to help limit the overall amount of demand and ensure that only counterparties most in need of liquidity would borrow. ${ }^{14}$ This premium pricing probably facilitated the rundown of dollar provision as market conditions improved.

47. Many central banks employed an exit strategy. Foreign exchange liquidity was in many cases provided with an explicit termination date, often conditioned on improved market liquidity.

Foreign exchange liquidity provision was effective and benign for central bank balance sheets

48. Central bank support for foreign exchange funding markets has been found to have been effective in reducing funding costs (Goldberg and others, 2011). According to market participants, central bank swap facilities improved term funding conditions in major off-shore funding markets (Baba and Packer, 2009). Mancini and Ranaldo (2010) found that central bank foreign exchange swaps reduced excess covered interest parity profits with a one-week lag. Aizenman and Pasricha (2010) found short-term but not long-term benefits from the Fed's swaps. Baba and Packer (2009), Stone and others (2009b), and Fung and Yu (2010) provide empirical evidence that central bank liquidity support and the Fed's extension of dollar swap lines reduced local foreign exchange market stress.

49. The impact of foreign exchange liquidity provision on the financial positions of central banks and local foreign exchange markets seems to have been minimal. No central banks appear to have incurred losses in providing foreign exchange liquidity. Nor did these operations appear to have caused a lasting contraction in foreign exchange market activity.

\footnotetext{
${ }^{14}$ When swap arrangements between the Fed and four central banks was reactivated in May 2010, the Fed clarified the modalities of the price setting of U.S. dollar provision by foreign central banks as follows: "The loans provided by the foreign central banks to institutions abroad are offered at rates that would be above market rates in normal times. As such, when market conditions are not greatly strained, demand for dollar liquidity through the swap lines should not be high, as market alternatives would be more attractive.” (Tarullo 2010).
} 


\section{B. Macroeconomic Stability Policies ${ }^{15}$}

\section{Several advanced economy central banks facing a lower interest rate bound turned} to unconventional balance sheet policies in support of macroeconomic stability. Emerging market economies have not turned to these policies because they are not constrained by a lower bound on interest rates (Figure 5), did not experience as severe economic downturns as did the advanced economies, and for them large increases in domestic liquidity could lead to destabilizing capital outflows (Ishi and others, 2009). These policies are in many respects outside the traditional purview of central banks. ${ }^{16}$

\section{Bond purchases}

51. Central bank bond purchases for macroeconomic objectives are to overcome the lower policy interest rate bound and are intended to lower long-term yields and boost aggregate demand. ${ }^{17} 18$ The potency of bond purchases follows from the capacity of the central bank to control its balance sheet, its potential access to fiscal resources as well as its market operation role and information advantages and monetary policy communication legacy. Bond purchases can be viewed as a shift from fixing a conventional short-term interest rate target to aiming to lower long-term yields. ${ }^{19}$

\section{By mid-2009, bond purchases took over from conventional interest rate policy as the main monetary policy tool for the Fed and the BoE. Bond purchases began in March 2009}

\footnotetext{
${ }^{15}$ This paper does not address the unconventional non-balance sheet monetary policy of committing to maintaining low interest rates for an extended period to boost aggregate demand, as was done by the Bank of Japan in the late 1990s and more recently by the BoC. See also Bernanke and others (2004) and Clouse and others (2000). The BoJ also made a commitment to keep its quantitative easing policy in the early 2000s (Oda and Ueda, 2007).
}

${ }^{16}$ They hark back to pre-Bretton Woods days when financial markets did not function as well. During the 1950s and 1960s, monetary policy analysis focused on portfolio substitution effects arising from imperfect substitutability between different assets (Tobin, 1958; Friedman, 1956).

${ }^{17}$ In this paper, the term "bond purchases" is shorthand for the central bank purchase of long-term public securities for macroeconomic objectives. These are different from purchases aimed at injecting liquidity into stressed government bond markets, as undertaken recently by the ECB with its Securities Market Programme. The discussion about bond purchases applies to purchases of mortgage backed securities (MBS) and Agency debts by the Fed as they are guaranteed or issued by government-sponsored agencies, although they also have some elements of liquidity support to credit markets (especially the initial purchases in late 2008) as well as central bank involvement in credit provision to the extent that they are targeted to a specific sector.

${ }^{18}$ Mechanically, bond purchases to banks involve the central bank receiving the securities while increasing bank reserves -increasing both sides of the central bank and bank balance sheets and shifting asset duration to the central bank. Purchases of bonds from non-bank investors involves the investor transferring the security to its bank in exchange for cash deposits (keeping the size of the investor balance sheet unchanged and shortening the duration of its assets), while the bank transfers the securities to the central bank in exchange for reserves at the central bank, again increasing both sides of the central bank and bank balance sheets.

${ }^{19}$ An extreme case is the Fed during 1942-51 when it maintained ceilings on Treasury yields at seven maturities (Toma, 1992). 
prompted by the dwindling effectiveness of conventional monetary policy culminating in policy interest rates brought to their lower bound (Figures 8 and 9). By mid-2010, the Fed and BoE bond purchases comprised large shares of the total outstanding stocks (Figure 10) and during some periods accounted for the bulk of government financing (Figure 11). In November 2010, the Fed announced another round of long-term government security purchases for the first half of 2011.

\section{There is no consensus on how bond purchases transmit}

\section{Bond purchases are often presented as transmitting to a large extent through} portfolio rebalancing. ${ }^{20}{ }^{21}$ The reduction in the outstanding stock available to market of the purchased security raises its price and lowers its yield, possibly by reducing the premium for duration or other types of risks (Gagnon and others, 2010; Krishnamurthy and VissingJorgensen, 2010a). ${ }^{22}$ The yields on long-term assets, such as corporate bonds and possibly bank loans, which are near substitutes for the security purchased by the central bank, are also reduced as investors rebalance their portfolio.

\section{A number of other channels from bond purchases to yields have been proposed} (Krishnamurthy and Vissing-Jorgensen, 2010b). These include: safety premium (purchases reduce yields for assets that serve a distinct safety role), interest rate commitment signal, default risk (bond purchases reduce likelihood of default), inflation expectations (purchases increase inflation expectations and lower real interest rates), and prepayment risk (MBS purchases lower yields). Some of these channels work through market segmentation that is at odds with the operation of portfolio balance effects.

\section{A variety of financial frictions have been employed in theoretical macroeconomic models for effective bond purchases. ${ }^{23}$ The model of Cúrdia and Woodford (2010), which has}

\footnotetext{
${ }^{20}$ Bond purchases have also been viewed as operating through a bank reserve channel whereby banks would lend out the cash they received for their long-term securities. For example, in 2000, the BoJ targeted a fixed level of bank reserves, suggesting that it expected transmission to go via bank balance sheets. More recently, the BoE also stressed the reserve liquidity enhancement channel. However, the reserve channel explanation of bond purchase transmission has come to be less emphasized by central banks. The model of Cúrdia and Woodford (2010) suggests that central bank asset purchases do not work through the reserve channel.

${ }^{21}$ Bond purchases, or other macroeconomic stability balance sheet policies, could also work by signaling a discrete break of the central bank from past cautious policies. This may have been the case when the Roosevelt administration adopted effective new expansionary policies in 1933 (Romer, 1992). This channel is not focused on here.

${ }^{22}$ Gagnon and others (2010) emphasize the amount of duration that is taken out of the stock of long-term securities available to investors. For example, the $\$ 300$ billion in completed Treasury purchases as of January 2010 was equal to $\$ 169$ billion 10-year equivalents. According to them, the more duration taken out of markets, the less risk faced by investors, and the lower the risk premium.

${ }^{23}$ Monetary theory has long disregarded the role of the central bank's balance sheet (cf Kohn, 2009). Many traditional models used for monetary policy analysis abstract altogether from the central bank's balance sheet by simply treating a short-term nominal rate as the sole control variable for the central bank's monetary policy operations (Cúrdia and Woodford, 2010). This follows Wallace (1981)’s “irrelevancy result” that both the size and
} 
heterogeneous households to motivate intermediation, financial frictions, and large financial shocks, imparts a policy role for central bank asset purchases. Gertler and Karadi (2009) allow for financial intermediaries with endogenous balance sheet constraints and central bank lending directly in private credit markets. Gertler and Kiyotaki (2009) go further by incorporating liquidity risks a la Kiyotaki and Moore (2008) and suggest that when private intermediaries are financially constrained central bank direct lending in private credit markets contribute to expansion of the overall supply of credit; otherwise, the central bank displaces private credit. The model of Del Negro and others (2010) imposes a liquidity constraint to get effective central bank bond purchases.

56. Bond purchases may also depreciate the exchange rate and lower yields on foreign assets. Under uncovered interest rate parity, a surprise decline in domestic long-term yields relative to those on foreign assets would lead to a one-off depreciation. Bond purchases could spill over into lower foreign yields to the extent that they are substitutable. Garcia-Cicco (2011) models balance sheet policies in an open economy setting.

\section{Bond purchases pose communication and exiting challenges}

57. In many respects, but not all, bond purchases have been implemented in different ways compared to the conventional monetary framework. The Fed and the BoE have made clear the objective of those bond purchases aimed at macroeconomic stability. Inflation expectations seem to be a forward-looking intermediate target-as with conventional monetary policy. ${ }^{24}$ In other respects, central banks are "learning by doing." The experience with bond purchases is so limited and transmission to inflation so uncertain that central banks seem to assign weights to other intermediate indicators such as key credit interest rates and flows as important indicators of ongoing effectiveness (e.g. Bernanke, 2009b). The yields on the purchased security are not quite an operating target under the control of the central bank (needless to say, central banks have only partial control over the outstanding stock of bonds) but could be viewed as an "operating indicator."

\section{The Fed and the BoE have provided considerable guidance on their exit strategies.}

The exit strategy involves timing the reduction of asset holdings and raising of policy rates and choosing the pace and measures of asset reduction. As these decisions will depend largely on future macroeconomic conditions, neither the Fed nor the BoE committed to a specific exit path. Nonetheless, both central banks have provided general guidance to avoid disorderly reactions from financial markets. For instance, both central banks have emphasized that the reduction of the asset and conventional monetary tightening can be undertaken separately; conventional

\footnotetext{
the composition of the central bank balance sheet should not matter for market equilibrium in frictionless financial markets-more precisely, (i) assets are valued only for their pecuniary returns and (ii) all investors can purchase arbitrary quantities of the same assets at the same prices.

${ }^{24}$ See the minutes of the Federal Open Market Committee (FOMC) for the September 21, 2010 meeting.
} 
tightening is likely to precede bond sales-if they are sold at all. ${ }^{25}$ In addition, the BoE, which holds around one fifth of government bonds, indicated that it will work closely with the debt management office in its resale of gilts (Fisher, 2010).

\section{Empirical work suggests that the recent bond purchases boosted asset prices and possibly aggregate demand as well ${ }^{26}$}

59. A number of event-type studies have concluded that bond purchases can alter asset prices. Studies of the U.K. and of the first round of bond purchases in the U.S. (Gagnon and others, 2010; Joyce and others, 2010; Dale, 2010; Krishnamurthy and Vissing-Jorgensen, 2010b; D’Amico and King, 2010) suggest that long-term security purchases may have reduced yields by 50-100 basis points on impact, and have lowered yields on near substitute securities. Gagnon and others (2010) argue that the impact of bond purchases on yields operated through lower risk premiums, including term premiums, as opposed to lower expectations of the future path of short-term policy interest rates. The announcement of the first round of bond purchases in the U.S. seemed to have boosted inflation expectations and thus contributed to a large reduction in real yields. The second round of bond purchases in the U.S. seems to have had a more limited effect (Krishnamurthy and Vissing-Jorgensen, 2010b). The event study of Lam (2011) found that government bond yields by the BoJ had a significant but small announcement impact on yields.

60. Several VAR and large model studies suggest that bond purchases provided the intended stimulus. Chung and others (2011) using a large policy model of the U.S. modified to capture the relationship between the term structure and Fed asset holds and estimate that the bond purchases of the Fed had a large expansionary impact. Using a time varying VAR model, Baumeister and Benati (2010) conclude that the bond purchases of the Fed and the BoE averted risks of deflation and large output contractions. Liu and others (2011) apply a regime-switching VAR model to the U.S. and conclude that the Fed's large scale asset purchases helped lower yields and contributed to lowering the unemployment rate and boosting inflation.

\section{However, the empirics is marked by analytical problems with offsetting implications}

61. Macroeconomic models do not capture the depression counterfactual and thus may be underestimating the benefits of bond purchases. The current state of the art models do not allow for the downside nonlinearities generated by systemic financial stress. This precludes assessment of the distance between actual outcomes and the depression counterfactual and thus inherently underestimates the policy benefits.

62. At the same time, standard analytical tools do not pick up the mostly forwardlooking costs and risks. Many of these risks arise from the fiscal-like aspects of bond purchases,

\footnotetext{
${ }^{25}$ Bernanke (2010b) and King (2010) discuss exit strategies.

${ }^{26}$ Bernanke and others (2004) review the earlier literature on the effectiveness of bond purchases.
} 
including their distributional consequences, as well the perception that these are to finance government spending. Others relate to central bank independence such as the exposure of central banks to vested interests. Exit challenges are a further risk. These risks and costs are quite hard to capture in a standard model.

\section{Central banks have not incurred losses so far}

\section{The recent Fed and $\mathrm{BoE}$ bond purchases so far seem not to have incurred central} bank losses. Central bank purchases of government bonds from the private sector financed by new bank reserves creates a maturity mismatch, leaving it vulnerable to an increase in interest rates. ${ }^{27}$ Further, bond purchases shorten the duration of the consolidated liabilities of the public sector.

\section{Large-scale foreign exchange purchases}

\section{Large-scale foreign exchange purchases are mainly aimed at countering protracted} upward pressure on the exchange rate also in the context of impaired transmission of conventional monetary policy. ${ }^{28}$ These purchases are unconventional in that they are of a larger order of magnitude than the amounts of two-sided intervention typical for the flexible exchange rate regimes operated by most major central banks. They can be used to counter protracted upward exchange rate appreciation pressure which can be costly for small open economies. There may also be a portfolio balance effect if demand is increased for other securities that transmit into higher aggregate demand. This policy is made possible by the central bank's foreign exchange policy role and information advantages which make it well-suited to judge whether the exchange rate is overvalued and that intervention is warranted. Large-scale foreign exchange purchases have not been sterilized and thus involved the creation of reserve money, which is another special power of central banks.

65. The Bank of Israel (BoI) and SNB undertook large foreign exchange purchases. The swiss franc and shekel appreciated rapidly beginning early in the crisis probably reflecting their "safe haven” status. Meanwhile, the policy interest rates of the BoI and SNB were reduced to historically low levels (Figure 9). The SNB purchases began in March 2009 and over the next year doubled the stock of reserves. ${ }^{29}$ The SNB stated that it bought foreign exchange to prevent further appreciation of the Swiss franc and thereby counter the growing risk of deflation. The

\footnotetext{
${ }^{27}$ The impact of interest rate changes on the central bank balance sheet depends on the adjustment of the yield curve, the exit strategy and accounting procedures (Appendix II).

${ }^{28}$ Svensson (2001) proposed large-scale foreign exchange intervention in support of a fixed exchange rate as a way to overcome the lower interest rate bound.

${ }^{29}$ In the late 1970s, the Swiss National Bank undertook large purchases of foreign exchange during a temporarily shift to a fixed exchange rate target prompted by a rapid appreciation (Kugler and Rich, 1992).
} 
BoI's intervention began in March 2008 in the context of rapid currency appreciation and its strategy of building up international reserves, continued in the format of regular amounts until early August 2009 and shifted to intervention in varying sums depending on market conditions. The reserves of the BoI also doubled. In both cases, reserve money rose broadly in line with foreign exchange reserves, suggesting that the purchases were not sterilized.

\section{Large-scale intervention seems to have been effective in the short-run but also costly}

\section{These policies seem to have at least temporarily countered appreciation pressure.}

Sorezcky (2010) found that the foreign exchange intervention of the BoI during 2008-09 resulted in a more depreciated value of the shekel than would have been the case otherwise. According to the SNB (2010), "The appreciation of the Swiss franc in early 2009 came to an abrupt halt following the SNB announcement in mid-March that it would prevent further appreciation by intervening in the foreign exchange market.” The intervention was seen by the SNB as countering appreciation pressures through the rest of 2009.

\section{The BoI and SNB incurred large losses in $\mathbf{2 0 1 0}$ from their exchange rate purchases.}

The appreciation of the Swiss franc and shekel generated losses for the BOI and SNB of 2.2 percent and 3.8 percent of GDP respectively. Foreign exchange valuation losses are not uncommon for central banks. ${ }^{30}$ However, the relatively large losses of the BoI and SNB is controversial.

\section{Central bank involvement in credit provision}

68. Central banks have taken measures to facilitate the provision of credit to a targeted sector to boost output. The transmission of central bank credit provision to domestic demand is more direct compared to bond purchases. Effective credit provision requires borrower demand at the dictated terms and feed through of the credit flow into higher aggregate demand and output. The need for credit provision need not follow from impaired monetary transmission. Central banks are able to undertake credit provision mainly due to their access to fiscal resources to deal with the contingent liability posed by credit risk. ${ }^{31}$ In developing economies, central banks may have an information advantage in identifying suitable projects or in discerning market failures. ${ }^{32}$

\footnotetext{
${ }^{30}$ In 2008, SNB recorded a net loss of 0.9 percent of GDP due to valuation losses of foreign reserves. Among other central banks, the ECB made a net loss of 1.6 billion euro or 0.02 percent of GDP due to valuation losses of foreign reserves in 2004.

${ }^{31}$ Indeed, in some models of unconventional monetary policy (e.g., Gertler and Karadi, 2009) the central bank has explicit fiscal powers.

${ }^{32}$ In command economies and many developing economies, gaps arising from the absence or incompleteness of markets led to a variety of roles for central banks in financial intermediation (Chandavarkar, 1996; Fry, 1993; Mackenzie and Stella (1996)). Central banks continue to play a financial development role in some countries (Alegieuno, 2008).
} 
69. Since 2007, major central banks have only taken a few measures with some aspects of credit provision. In the past, many central banks undertook credit provision on a large scale, but major central banks have generally stopped this practice. ${ }^{33}$ The measures with some elements of credit provision followed the hitting of the lower interest rate bound on conventional monetary policy. The later MBS/GSE bond purchases of the Fed have an element of credit provision in that they were intended to benefit the housing sector, although these securities are claims on another public entity and thus pose no credit risk to the Fed. The "Asset Purchase Program" announced by the BoJ in October 2010 includes the purchase of commercial paper, corporate bonds, exchange-traded funds and real estate investment trusts. In June 2010, the BoJ announced a facility to provide collateralized low interest rate long-term funds to banks to finance credit to sectors deemed to strengthen the foundation for economic growth. The BoJ stepped up its credit provision facilities following the earthquake and tsunami of March 2011. Again, these measures have not posed meaningful credit risk to the BoJ.

70. Assessment of the success in boosting credit of these measures is difficult. Central banks undertook credit provision in the past, but in many cases incurred losses and moved away from this role (Fry, 1993). The impact of the Fed's MBS/GSE purchases on credit flows is difficult to gauge and the aforementioned facilities of the BoJ have not been in place long enough to assess.

\section{Adding Balance Sheet Policies to the Standard Central Bank Toolkit}

71. This section discusses addition of the recent unconventional balance sheet policies to the central bank toolkit. Many central banks—not only those that recently utilized them-are considering adding unconventional balance sheet policies to their toolkit. This section is meant to inform these considerations.

72. It is worth emphasizing again that the following discussion is preliminary and necessarily general. This reflects, first, a lack of counterfactuals. Ideally, any policy assessment compares outcomes of when the policy is used and when it is not. However, there have been too few episodes of systemic financial instability and a binding lower interest rate bound in modern times to afford analysis of the counterfactual. Further, the discussion here is cast in general terms, but, of course, the decision to adopt unconventional balance sheet policies depends very much on the country specifics.

\section{A. Financial Stability Balance Sheet Policies}

\section{Unconventional financial stability balance sheet policies are relevant for any} country with systemically important credit, fund and foreign exchange markets. Thus, they warrant consideration by a large number of central banks.

\footnotetext{
${ }^{33}$ For example, in its 1987 Annual Report the Banco de Portugal reported that interest rate subsidies were the equivalent of some 50 percent of its reported profits.
} 
The case for including liquidity support to domestic markets in the toolkit is strong

74. There is by now considerable empirical evidence supporting the effectiveness of market liquidity support. Empirical analysis broadly concludes that liquidity provision has alleviated stress in the targeted markets. In almost all cases, this support has already been exited from with apparent little disruption.

75. The main risks involve market risks to the central bank balance sheet, the moral hazard of further future support, and crowding out of markets (Box 1). Market support inherently involves credit risk. Encouragingly, central banks do not seem to have incurred losses from domestic liquidity support. The moral hazard of enhanced expectations of support in the future is another risk. The supplanting of markets by central bank liquidity provision is another potentially important consequence with costs that may be realized over the long run. Differentiating this support from monetary policy is another challenge.

76. Central banks are certainly best suited to undertake market liquidity support. Credit market liquidity support involves credit risk and some degree of government involvement, although central banks are best suited to conduct this policy but because of their information and operational advantages as well as the need for coordination with monetary policy.

77. Some of the liquidity broadening elements introduced by central banks during the crisis may be worth retaining (IMF, 2010a). Enhanced flexibility of liquidity provision could facilitate liquidity management during normal circumstances and provide more options during periods of systemic stress. Particular elements of expanded liquidity provision that could be retained are higher reserve levels (especially for economies in which the level of required reserves in normal conditions is low), a sufficient set of counterparties for flexible liquidity provision, sufficient and properly priced eligible collateral, measures to reduce stigma (a bank being unwilling to borrow from the central bank owing to its concern that by doing so it would send a signal to the markets that it was uncreditworthy) such as anonymity in liquidity access, and effective funds-absorbing tools (central bank bills and an ability to remunerate central bank deposits) can enhance liquidity management during normal conditions and absorb large-scale liquidity injections. 


\section{Box 1. Challenges and Risks Posed by Liquidity Provision}

Many of the challenges and risks are posed by both domestic and foreign exchange support:

- Coordination of liquidity provision with monetary policy-Central banks can face the challenge of ensuring that liquidity provision for financial stability purposes is not confused for an unwanted loosening of monetary policy (cf Stark, 2008).

- Market distortions - Liquidity provision targeted at particular markets can tilt the playing field in favor of the selected market players. Central banks providing access to liquidity cannot know for sure which counterparties would not be able to obtain financing otherwise, or which counterparties are healthy and taking advantage of easy terms.

- Moral hazard-Large-scale liquidity provision can lead to expectations of support in the future.

- Crowding out of funding markets-The supplanting of money markets by the central bank can, over time, shrink the supporting infrastructure, and lead banks to cut back on their own market-based liquidity management. Once markets do recover, the fixed costs of rebuilding these capabilities would have to be repaid.

- Potential credit risks for the central bank-In a crisis situation, central banks cannot be assured that their financing is addressing a liquidity or solvency problem.

- Exposure of central banks to vested interests - The liquidity provision to targeted borrowers leaves central banks vulnerable to pressure from vested interests eager to take advantage of easy access to liquidity even after conditions improve.

Others are specific to foreign exchange liquidity support:

- Coordination of foreign exchange liquidity provision with exchange rate policy-Central banks must draw a line to the extent possible between foreign exchange intervention to influence the exchange rate for macroeconomic objectives and measures to boost foreign exchange liquidity. This is more difficult for countries that intervene regularly and with discretion.

- Insurance issue and coordination with international arrangements-To the extent that foreign exchange liquidity provision serves an insurance function should be assessed together with other insurance mechanisms, such as the appropriate level of international reserves, IMF facilities, and access to market borrowing. 


\section{Likewise, a strong case can be made for foreign exchange liquidity support}

78. Foreign exchange liquidity measures also seem to have been effective. Again, there is considerable empirical support that these measures reduced local foreign exchange funding costs and enhanced availability. Further, central bank swaps seem to have played an important role in reducing market stress.

79. The main risks seem to be with respect to foreign exchange policy and moral hazard (Box 1). Separating out foreign exchange liquidity provision from exchange rate policy can be problematic. Markets may have incentive to take riskier behavior if foreign exchange liquidity support can be expected in times of stress. Foreign exchange liquidity provision seems not to have crowded out local markets or caused central bank losses.

\section{B. Macroeconomic Stability Balance Sheet Policies}

80. The use of macroeconomic stability balance sheet policies by only a few central banks facing a lower interest rate suggests that their forward-looking policy relevance is fairly limited. These policies were employed by highly credible central banks with reserve or safe haven currencies that are so credible that investors are willing to hold them even when they earn an almost zero nominal return. The lower interest rate bound compels these central banks to turn to bond or foreign exchange purchases. Central banks that do not face the lower interest rate bound need not resort to macroeconomic stability balance sheet policies. Further, adding these policies to the toolkit does not mean they should be an ongoing tool; rather, their use should be conditional on being at the lower interest rate bound.

\section{Bond purchases have been effective to a degree and there are risks}

81. Bond purchases almost surely pushed down long-term yields in the U.S and U.K. The feed-through from lower yields to aggregate demand seems to have been positive but is not well established. The effectiveness of bond purchases probably declines on the margin. They are a relevant policy for highly credible banks constrained by the lower interest rate bound.

82. Bond purchases do pose a range of potential costs and risks (Box 2). Exiting may prove to be challenging. Costs include a loss of market pricing information, and a potential balance sheet impact for the central bank. There are also adverse potential fiscal implications, such as monetization of a government deficit, which can delay fiscal consolidation and, in the worst case, can undermine confidence in the fiscal authorities.

83. The central bank can be seen as the best-suited vis-à-vis the government to implement bond purchases for the purpose of influencing aggregate demand. The distributional implications of bond purchases are inter-temporal and relatively limited. The central bank has considerable information advantages over the government in assessing the effectiveness and transmission of bond purchases. Further, bond purchases to reduce yields is a logical extension of interest rate policy conducted by the central bank. 


\section{Box 2. Challenges Posed by Bond Purchases and Credit Provision}

Some of the challenges and risks are common to both bond purchases and credit provision:

- $\quad$ Distributional consequences - Lower long-term yields generated by bond purchases bring an inevitable intertemporal distortion by helping debtors (usually young) at the expense of savers (usually old). Credit provision is necessarily targeted at specific borrower classes and thus generates intersectoral distortions. Democratic accountability is a guiding precept for any public sector entity that implements policies with distributional effects, and thus these policies are not well-suited for central banks.

- $\quad$ Loss of market price information-The market price of intervened securities will, if policy is effective, be distorted, removing a key market indicator.

- $\quad$ Financial impact on the central bank-A increase in bond yields causes valuation losses for the central bank if the purchased bonds or loans are valued at market prices. The central bank will incur a capital loss from outright sales of the securities if yields have increased. If the central bank chooses to hold the securities to maturity, its net income will decrease as the central bank raises policy rates and liability costs rise. Credit provision can expose central banks to credit risks, depending on the design.

- $\quad$ Exposure of central banks to vested interests-The channeling of credit to targeted borrowers leaves central banks vulnerable to pressure from vested interests eager to access these resources. Such pressure could compromise the autonomy that is important for effective central bank financial and macroeconomic stability policies. Further, vested interests could strive to complicate or delay exiting from credit provision or bond purchases.

Other challenges and risks are specific to bond purchases:

- $\quad$ Communication challenges - Central bank communication of bond purchases is challenging because their transmission is not well understood. Further, markets are accustomed to receiving information about supply conditions of government bonds from debt managers, rather than from central banks.

- $\quad$ Exit challenges - An exit strategy is needed as these purchases are motivated by temporarily impeded conventional monetary policy (IMF, 2009) and because they are long-term. Exiting from bond purchases is more challenging than tightening conventional monetary policy as it requires decisions regarding involving liquidity absorbing, raising the policy interest rate from its lower bound, and taking a view on how to treat long-term yields.

- $\quad$ Impact on consolidated public sector balance sheets and income-Bond purchases shorten the duration of consolidated public sector debt and thus alter the expected path of public financing costs (Appendix III). The "capital loss" and "income loss" of the central bank described above would increase the effective financing costs on a consolidated sovereign basis. In addition, this could raise rollover risk for economies with large fiscal burdens.

- $\quad$ Perception of monetization of government debt-Central bank bond purchases in the context of a fiscal deficit can be perceived as (indirect) monetary financing and lead to volatile and higher bond yields to compensate for the risk of inflationary financing. 
Large-scale foreign exchange intervention seems to have been effective in the short-run but also costly for central banks

84. This policy seems to have had some short-run success in alleviating upward exchange rate pressure. However, a definitive conclusion cannot be drawn here owing to the many factors that drive exchange rate movements. Further, the alleviation of upward pressure on the exchange rate may not be sustainable.

85. There are considerable national and multilateral risks. The risks for the country are to the perceived commitment of the central bank to a flexible exchange rate and the exposure of the financial position of the central bank (and the public sector) to exchange rate risk from large foreign exchange holdings. From a multilateral perspective, foreign exchange intervention on a large scale has the potential to generate foreign exchange policy reactions from other countries that could lead in a worst case scenario to a devaluation spiral across countries.

The case for credit provision by central banks is weak

86. Central banks are not well suited for undertaking targeted credit provision. Most major central banks have limited or no information advantage over the private sector in identifying creditworthy projects. Credit provision has distributional implications and involves fiscal resources and is thus best undertaken by the government which is more democratically accountable than the central bank. Except in the most exceptional circumstances credit provision is best done by the government, possibly in cooperation with the central bank.

87. The risks for a central bank are high, including market risks, moral hazard, and potential threats to central bank independence. The historical experience of directed central bank credit provision has often been quite negative, as it was seen as compromising central bank independence and monetary policy objectives.

\section{Implementing Balance Sheet Policies}

88. Adding balance sheet policies to the toolkit poses tricky challenges. This section briefly considers how these policies fit into the broad policy framework, discusses best practices, and presents a forward-looking downside scenario as a note of caution.

Unconventional balance sheet policies within the broad policy framework

89. Fitting balance sheet policies into the policy framework raises novel choices and tensions. Of course, identifying the exceptional circumstances that warrant their use is a central challenge in employing unconventional central bank balance sheet policies. A related issue is coordinating them with regulatory, liquidity and fiscal policies-a point which is stressed in the next subsection. A few specific observations on the policy mix in different settings follow.

90. A credible fiscal consolidation when interest rates are at their lower bound can enhance the effectiveness of macroeconomic stability balance sheet policies. Research (IMF, 2010b; Christiano and others, 2009) suggests that fiscal consolidation has a bigger output cost for an economy at the lower bound than otherwise because the central bank cannot lower rates to 
cushion the contractionary fiscal impulse. In this setting, not only can bond purchases help ease monetary conditions but their risks are attenuated by the positive signal conveyed by fiscal consolidation.

91. When systemic financial stress is the primary concern, liquidity providing operations can be set apart from monetary policy. This helps reassure markets that the central bank is meeting liquidity needs rather than possibly boosting inflation above its target. Such was the situation in most of the large advanced economies during mid-2007 to late-2008 and in the euro area since mid-2010.

92. When systemic financial stress prevails and the policy interest rate is at its lower bound, a single balance sheet policy can help both the financial system and the economy at large. In these circumstances, bond purchases can both help relieve bond market stress and reduce long-term yields. Liquidity provision relieves stressed financial markets and facilitates monetary transmission. Further, these policies can help improve overall confidence by signaling the resolve of the authorities.

\section{Best practices of implementing balance sheet policies}

93. Appendix III elaborates best practices balance sheet policy implementation drawn from a review of central bank practices and the pre-crisis experience with conventional policies. ${ }^{34}$ As noted in section II, in many respects monetary policy frameworks converged during the "golden age" of central banking. However, there is not yet a consensus for best practices for unconventional balance sheet policies. The discussion here is motivated by the unique aspects of these policies including their conditionality and limited duration, policy overlaps and coordination, the associated disequilibria of markets and economies, and the concomitant balance sheet risks. Not taking these differences fully into account in designing and implementing balance sheet policies can result in the realization of the risks laid out in boxes 1 and 2 (Shirakawa, 2010).

94. The elaboration of best practices is meant to help the pitfalls (Box 3). Enough experience has been gained with these policies to begin to point to best practices. Thus, Appendix III is meant to provide initial guidance and help advance thinking on how to implement unconventional balance sheet policies. They are based on what can be viewed as the successful elements of balance sheet policies used by central banks, as well as on what was learned from the development of the pre-crisis framework. In some respects, implementation does not involve difficult tradeoffs; for example balance sheet protection and policy coordination. However, there are two particularly difficult challenges.

\footnotetext{
${ }^{34}$ Individual central banks have presented implicit or explicit “principles” regarding aspects of balance sheet policies (Bank of Canada, 2009; Tucker, 2009; Bank of Japan, 2009).
} 
95. The first challenge is finding the right balance on transparency. Transparency can be defined in the context of this paper as the public's ability to understand the central bank's motives and actions (Carpenter, 2004). It is generally recognized that there are limits on transparency in monetary policy (Mishkin, 2002). In particular, the conventional balance sheet policies of liquidity support to banks and foreign exchange intervention are less transparent than monetary policy (IMF, 2005). Real time transparency in support to stressed banks or other financial institutions runs the risk of generating a destabilizing run on deposits, thus the practice of "constructive ambiguity" (Enoch and others, 1997). If the public underestimates the degree of uncertainty surrounding the desired policy outcomes expressed by central banks, than guidance that turns out to be inaccurate ex post could be destabilizing. Clearly, systemic financial instability and impaired monetary transmission - the circumstances that warrant unconventional balance sheet policies_-are highly uncertain states of the world.

\section{Implementing balance sheet policies poses a difficult transparency challenge.}

Transparency in the goals and instruments of balance sheet policies would seem to enhance their effectiveness. In contrast, there may often be too much uncertainty for full clarity in their implementation, especially in how the central bank communicates its views on transmission. However, central banks can look at the "substitutability" of different aspects of implementation (e.g. trading off transparency on the timing of versus the conditions for exiting).

97. Ex post transparency of balance sheet policies facilitates democratic accountability. While ex ante transparency may not be desirable given the uncertainties associated with balance sheet policies, ex post transparency on their implementation and outcome fosters accountability and overall central bank credibility.

98. The second challenge has to do with the tradeoffs between effectiveness and distortions. While conventional monetary policy aims at market neutrality, balance sheet policies by their nature are targeted at specific markets. The narrower the targeted market, the greater the risk of distortion. Central banks can face difficult tradeoffs between the costs of these distortions against attainment of their policy objectives. Not much more can be said about which way to lean on this tradeoff except that this is conditional on the country setting and stability considerations.

\section{The downside fiscal dominance scenario}

99. In the post-crisis setting, adding central bank policies to the toolkit has the potential to contribute to a downside destabilizing dynamic. The recent crisis was unexpected and severe led to large increases in the size and interlinkages of the balance sheets of governments, central banks and financial sectors. Risks remain in the outlook and some small steps have been taken that undermine central bank independence (Stella, 2010). 


\section{Box 3. Best Practices of Central Bank Balance Sheet Policies}

\section{Objectives, Transparency, and Accountability}

1. The objectives and broad framework of balance sheet policies should be clearly set out in terms of the central bank policy mandate.

2. The central banks should explain to the extent possible the expected transmission mechanism and risk of balance sheet policies.

3. The central banks should make public the details of the operational design of balance sheet operations, including terms and conditions of auctions and their actual use.

4. The central banks should periodically explain progress in achieving policy objectives through balance sheet policies.

\section{Policy Coordination}

5. Financial stability balance sheet policies should be complemented by supervisory and regulatory measures and consistent with the crisis management strategy.

6. Central banks' balance sheet policies should be clearly delineated from fiscal policies.

\section{Operational Designs and Exit Strategies}

7. Central banks should have sufficient legal and operational flexibility for balance sheet policies.

8. Balance sheet policies should be designed to minimize distortions, including moral hazard and resource misallocation.

9. Exit strategies from balance sheet policies should be developed and clearly communicated at the time of their introduction.

\section{Central Bank Balance Sheet Protection}

10. Measures to protect central bank balance sheets should be clearly communicated.

11. For lending operations, risk management tools, such as collateral, pricing, and haircuts, should be used based on the differential risks of each policy.

12. Private debt instruments for outright purchase or collateral for lending operations should be high quality.

13. The central banks should have sufficient financial strength and the extent of their risk taking should be agreed with the government, including an ex ante mechanism to transfer resources to the central bank if needed. 
100. The destabilizing dynamic begins as follows. A major central bank may not be able to exit from its balance sheet policies (sell government bonds and foreign exchange, withdrawing from money markets) for years. ${ }^{35}$ A moral hazard arises under which the government pressures its increasingly "captured" central bank to further widen the policy scope. A government with a relatively short-term horizon has reason to take behavior risky for the economy at large feeling confident that it can depend on the central bank to provide support if these policies fail. The prospect of this support gives the government less reason to pursue politically painful fiscal consolidation and financial reforms. ${ }^{36}$

101. Importantly, this dynamic could repeat with larger social losses in each round. First, increasing "fiscal capture" means that the central bank intervenes earlier and on a larger scale. Second, under Ricardian equivalence, the impact of central bank quasi-fiscal policies on aggregate demand would be offset by higher private savings. Third, these policies increase the public debt and taken to the extreme will be counterproductive. The downside risk is that this repeated game scenario boosts economic and financial volatility. This was the case in the past with some developing and emerging market countries where governments dominated the central bank.

102. Sound application of unconventional policies and other supporting policies would militate against this scenario. As stressed earlier in this section, balance sheet policies should be used only in special circumstances for financial and macroeconomic stability purposes and when other instruments are not effective. Much has been learned in the past three years and application of the best practices of central banks documented in Appendix III would help. A clear delineation between fiscal, monetary and financial sector policies also as described in Appendix III helps prevent the government from pressuring the central bank to move into the quasi-fiscal realm. Of course, long-term fiscal consolidation takes the pressure off monetary policy and the central bank. Finally, any measures that impinge on central bank independence should be avoided.

\section{Conclusion}

103. Many of the recent central bank unconventional balance sheet policies likely warrant inclusion in the toolkit depending on the country and the circumstances. The adoption of these policies probably marks one of the most radical and rapid shifts in policy in recent central bank history. The financial stability balance sheet policies look to warrant inclusion in the toolkit of many central banks. Bond and foreign exchange purchases for macroeconomic stability policies are relevant for highly credible central banks in the unusual

\footnotetext{
${ }^{35}$ Angeloni and Faia (2010) model different policy mix exit scenarios.

${ }^{36}$ Reinhart and Sbrancia (2011) document how governments during the late 1940s to the 1970s reduced debt by various means of "financial repression", some of which involved central banks.
} 
circumstances of the lower interest rate bound. The case for central bank credit provision is weak. A definitive judgment on balance sheet policies won’t be possible for some years, especially with regards to the risks.

104. Adding unconventional balance sheet policies is not straightforward because they involve a wide array of policies. Folding balance sheet policies into the new post-crisis economic policy frameworks will be part of the fundamental review of economic policies now underway (Blanchard and others, 2010). The financial stability balance sheet policies will need to be integrated into new crisis management and regulatory frameworks. This is a short-term priority because the market liquidity support policies have been mostly exited from with success and thus can be designed with some confidence and there may be lingering stability risks in the global financial system.

105. A cautionary final thought is in order. Central banks and governments are faced with the challenges of exiting smoothly from balance sheet and other crisis intervention policies, clarifying the new wider set of central bank policy responsibilities, and reducing in some cases very large fiscal burdens. As noted in the previous section, this setting raises the potential of a downside scenario involving the misuse of balance sheet policies and a loss of central bank independence. The preservation of the historically large measure of credibility gained by central banks during the pre-crisis golden age will hinge on meeting successfully these challenges. 


\section{REFERENCES}

Adrian, Tobias, Karin J. Kimbrough, and Dina Marchioni, 2010, “The Federal Reserve’s Commercial Paper Funding Facility,” FRB of New York Staff Report No. 423, April.

Aït-Sahalia, Yacine, Jochen Andritzky, Andreas Jobst, Sylwia Nowak, and Natalia T. Tamirisa, 2009, "How to Stop a Herd of Running Bears? Market Response to Policy Initiatives during the Global Financial Crisis,” IMF Working Paper, September.

Alegieuno, Joe, 2008, "Rationalising the Role of Central Banks in Development Financing," Central Bank of Nigeria, presented at the 2nd Central Bank Forum organised by AFRACA, Lusaka, Zambia, September 23-25.

Angeloni, Ignazio and Ester Faia, 2010, “Exit Strategies,” Mimeo, December.

Artuç, Erhan, and Selva Demiralp, 2009, "Provision of Liquidity through the Primary Credit Facility during the Financial Crisis: A Structural Analysis,” FRBNY Economic Policy Review.

Aizenman, Joshua and Gurnain Kaur Pasricha, 2010, “Selective Swap Arrangements and the Global Financial Crisis: Analysis and Interpretation,” International Review of Economics and Finance 19, 353-365, January.

Baba, Naohiko, Motoharu Nakashima, Yosuke Shigemi and Kazuo Ueda, 2006, "The Bank of Japan's Monetary Policy and Bank Risk Premiums in the Money Market," International Journal of Central Banking, Vol. 2(1), March.

Baba, Naohiko and Frank Packer, 2009, "From turmoil to crisis: dislocations in the FX swap market before and after the failure of Lehman Brothers,” BIS Working Paper No 285, July.

Baba, Naohiko, Robert N. McCauley and Srichander Ramaswamy, 2009, "US Dollar Money Market Funds and Non-US Banks,” BIS Quarterly Review, March.

Bagehot,Walter, 1878, Lombard Street: A Description of the Money Market (New York: Charles Scribner's Sons).

Bank of International Settlements, Market Committee, 2009a, "Monetary Policy

Frameworks and Central Bank Market Operations,” MC Compendium, May.

Bank of International Settlements, 2009b, Government Debt Management at Low Interest Rates,” BIS Quarterly Review, p 35-51, June.

Bank of Japan, 2009, “Outright Purchases of Corporate Financing Instruments,” January. 
Baumeister, Christiane and Luca Benati, 2010. "Unconventional Monetary Policy and the Great Recession-Estimating the Impact of a Compression in the Yield Spread at The Zero Lower Bound," European Central Bank Working Paper 1258.

Bean, Charles, 2009, “Quantitative Easing: An Interim Report", speech to the London Society of Chartered Accountants.

Bernanke, Ben, 2004, “The Great Moderation,” remarks at the 2004 Eastern Economic Association meetings, Washington D.C.

Bernanke, Ben S., Vincent R. Reinhart, and Brian P. Sack, 2004, "Monetary Policy Alternatives at the Zero Bound: An Empirical Assessment," Brookings Papers on Economic Activity, vol. 2004 (2), pp. 1-78.

Bernanke, Ben S., 2009a, “The Crisis and the Policy Response,” the Stamp Lecture, London School of Economics, London, England, January 13.

Bernanke, Ben S., 2009b, "Federal Reserve Policies to Ease Credit and Their Implications for the Fed's Balance Sheet,” Speech at the National Press Club Luncheon, National Press Club, Washington, D.C., February 18.

Bernanke, Ben S., 2009c, “The Federal Reserve's Balance Sheet,” Speech at the Federal Reserve Bank of Richmond 2009 Credit Markets Symposium, Charlotte, North Carolina, April 3.

Bernanke, Ben S., 2010a, "Implications of the Financial Crisis for Economics," Speech at the Conference Co-sponsored by the Center for Economic Policy Studies and the Bendheim Center for Finance, Princeton University, Princeton, New Jersey, September 24.

Bernanke, Ben S., 2010b, “Federal Reserve's Exit Strategy,” Testimony before the Committee on Financial Services, U.S. House of Representatives, Washington, D.C., February 10.

Bini Smaghi, Lorenzo, 2009, “Conventional and Unconventional Monetary Policy,” Keynote lecture at the International Center for Monetary and Banking Studies (ICMB), Geneva, April 28, 2009.

Blanchard, Olivier, Giovanni Dell’Ariccia, and Paolo Mauro, 2010, "Rethinking Macroeconomic Policy,” IMF Staff Position Note 10/03, February.

Borio, Claudio and Piti Disyatat, 2009, “Unconventional Monetary Policies: An Appraisal,” BIS Working Paper No. 292, November.

Calvo, Guillermo, 2006, "Monetary Policy Challenges in Emerging Markets: Sudden Stop, Liability Dollarization, and Lender of Last Resort,” NBER Working Paper No. 12788, December. 
Bank of Canada, 2009, Monetary Policy Report, April.

Carpenter, Seth, 2004, “Transparency and Monetary Policy: What does the Academic Literature Tell Policymakers?” Federal Reserve Finance and Economics Discussion Series 2004-35, April.

Celasun, Oya and Geoffrey Keim, 2010, "The U.S. Federal Debt Outlook: Reading the Tea Leaves,” IMF Working Paper 2010/62, March.

Chandavarkar, Anand, 1996, “Central Banking in Developing Countries,” Macmillan, London.

Chailloux, Alexandre, Simon Gray, Ulrich H.Klueh, Seiichi Shimizu, and Peter Stella, 2008, "Central Bank Response to the 2007-08 Financial Market Turbulence: Experiences and Lessons Drawn,” IMF Working Paper No. 08/210, October.

Christiano, Lawrence, Martin Eichenbaum, Sergio Rebelo, 2009, "When is the Government Spending Multiplier Large?” NBER Working Paper No. 15394, October.

Chung, Hess, Jean-Philippe Laforte, David Reifschneider, and John C. Williams, 2011, "Have We Underestimated the Probability of Hitting the Zero Lower Bound?,” Federal Reserve Bank of San Francisco Working Paper 2011-01, January.

Clouse, James, Dale Henderson, Athanasios Orphanides, David Small, and Peter Tinsley, 2000, "Monetary Policy When the Nominal Short-Term Interest Rate is Zero," Federal Reserve Board Finance and Economics Discussion Series 2000-51, November.

Cúrdia, Vasco, and Michael Woodford, 2010, "The Central-Bank Balance Sheet as an Instrument of Monetary Policy,” Journal of Monetary Economics, forthcoming.

Dale, Spencer, 2010, “QE—One Year On”, Remarks at the CIMF and MMF Conference, Cambridge New Instruments of Monetary Policy: The Challenges, March 12.

D'Amico, Stefania, and Thomas B. King, 2010, "Flow and Stock Effects of Large-Scale Treasury Purchases," Finance and Economics Discussion Series 2010-52. Washington: Board of Governors of the Federal Reserve System, September.

Del Negro, Marco, Gauti Eggertsson, Andrea Ferrero, Nobuhiro Kiyotaki, 2010, “The Great Escape? A Quantitative Evaluation of the Fed's Non-Standard Policies,” Mimeo, Federal Reserve Bank of New York, March.

De Kock, M. H., 1974, Central Banking, London: Crosby Lockwood Staples.

Disyatat, Piti, 2008, "Monetary Policy Implementation: Misconceptions and Their Consequences,” BIS Working Paper No 269, December. 
Eggertsson, Gauti, and Michael Woodford. 2003, “The Zero Bound on Interest Rates and Optimal Monetary Policy,” Brookings Papers on Economic Activity, 139-233, March.

Enoch, Charles, Peter Stella and May Khamis, 1997, “Transparency and Ambiguity in Central Bank Safety Net Operations,” IMF Working Paper No. 97/138, October.

Fahr, Stephan, Roberto Motto, Massimo Rostagno, Frank Smets and Oreste Tristani, 2010, "Lessons for Monetary Policy Strategy From the Recent Past,” November.

Fisher, Paul, 2010, “An Unconventional Journey: The Bank of England's Asset Purchase Programme,” Speech at the Bank’s Agency for the South-West Stonehouse Court, Gloucestershire, October 11.

Fleming, Michael J., Warren B. Hrung, Frank M. Keane, 2010, "Repo Market Effects of the Term Securities Lending Facility,” Staff Report No. 426, January.

Friedman, Benjamin and Kenneth N. Kuttner, 2010, "Implementation of Monetary Policy: How Do Central Banks Set Interest Rates?” NBER Working Paper No. 16165, July.

Friedman, Milton (Ed.), 1956, “Studies in the Quantity Theory of Money,” Chicago: University of Chicago Press.

Fry, Maxwell J., 1993, “The Fiscal Abuse of Central Banks,” IMF Working Paper No. 93/58, July.

Fung, Laurence and Ip-wing Yu, 2010, “Dislocations in the FX Swap and Money Markets in Hong Kong SAR During the Global Credit Crisis of 2007-08,” in The Global Crisis and Financial Intermediation in Emerging Market Economies, BIS Paper No 54, December.

Gagnon, Joseph, Matthew Raskin, Julie Remache, and Brian Sack, 2010, "Large-Scale Asset Purchases by the Federal Reserve: Did They Work?” Federal Reserve Bank of New York Staff Report 441.

Giannone, Domenico, Michele Lenza, Huw Pill and Lucrezia Reichlin, 2011, "Non-Standard Monetary Policy Measures and Monetary Developments, ECB Working Paper No 1290, January.

Galí, Jordi, and Luca Gambetti. 2009. "On the Sources of the Great Moderation." American Economic Journal: Macroeconomics, 1(1): 26-57.

Garcia-Cicco, Javier, 2011, “On the Quantitative Effects of Unconventional Monetary Policies in Small Open Economies,” International Journal of Central Banking, forthcoming. 
Gerlach, Stefan, Alberto Giovannini, Cédric Tille, and José Viñals, 2009, “Are the Golden Years of Central Banking Over? The Crisis and the Challenges,” Geneva Reports on the World Economy, 10.

Gertler, Mark, and Peter Karadi, 2009, “A Model of Unconventional Monetary Policy," Unpublished, New York University, November.

Gertler, Mark and Nobuhiro Kiyotaki, 2010, "Financial Intermediation and Credit Policy in Business Cycle Analysis,” Mimeo, March.

Goldberg, Linda, Craig Kennedy and Jason Miu, 2011, “Central Bank Dollar Swap Lines and Overseas Dollar Funding Costs,” Federal Reserve Bank of New York Economic Policy Review, Forthcoming Spring.

Goodhart, Charles, 1988, “The Evolution of Central Banks,” MIT Press.

Goodhart, Charles, 2010, “The Changing Role of Central Banks,” BIS Working Paper No. 326, November 2010.

Hamilton, James D., and Jing Wu, 2010, "The Effectiveness of Alternative Monetary Policy Tools in a Zero Lower Bound Environment," Working paper. San Diego: University of California, San Diego.

Hirose, Yasuo and Shinsuke Ohyama, 2010, “Identifying the Effect of the Bank of Japan's Liquidity Facilities: The Case of Commercial Paper Operations During the Financial Turmoil. International Finance,” 13: 461-483, Winter.

International Monetary Fund and World Bank, 2000, Guidelines for Public Debt Management.

International Monetary Fund, 2005, "Selected Country Experience in Implementing the Code of Good Practices on Transparency in Monetary and Financial Policies,” SM/05/334 (Washington: International Monetary Fund).

International Monetary Fund, 2010a, “Exiting from Monetary Crisis Intervention Measures,” IMF Policy Paper; January.

International Monetary Fund, 2010b, "Will It Hurt? Macroeconomic Effects of Fiscal Consolidation,” Chapter 3 of World Economic Outlook, October.

International Monetary Fund, 2010c, “Central Banking Lessons from the Crisis,” July.

International Monetary Fund, 2010d, “Systemic Liquidity Risk: Improving the Resilience of Institutions and Markets,” Chapter II of Global Financial Stability Report, October. 
Ishi, Kotaro, Mark R. Stone, and Etienne B. Yehoue, 2009, "Unconventional Central Bank Measures for Emerging Economies,” IMF Working Paper No. 09/226, September.

Joyce, Michael, Ana Lasaosa, Ibrahim Stevens and Matthew Tong, 2010, “The Financial Market Impact of Quantitative Easing,” Bank of England Working Paper No. 393, July.

King, Mervyn, 2010, Speech at the Lord Mayor's Banquet for Bankers and Merchants of the City of London at the Mansion House, June 16.

Kiyotaki, Nobuhiro and John Moore, 1997, "Credit Cycles", Journal of Political Economy 105 (2): 211-248,

Kiyotaki, Nobuhiro and John Moore, 2008, “Liquidity, Business Cycles, and Monetary Policy,” Mimeo, April.

Klyuev, Vladimir, Phil De Imus, and Krishna Srinivasan, 2009, “Unconventional Choices for Unconventional Times Credit and Quantitative Easing in Advanced Economies,” IMF Staff Position Note No. 2009/27, October.

Kohn, Donald, 2009, "Monetary Policy Research and the Financial Crisis,” Speech delivered at Washington D.C., October 9.

Krishnamurthy, Arvind and Annette Vissing-Jorgensen, 2010a, “The Aggregate Demand for Treasury Debt,” Mimeo, May.

Krishnamurthy, Arvind and Annette Vissing-Jorgensen, 2010b, “The Effects of Quantitative Easing on Long-term Interest Rates,” Mimeo, November.

Kugler, Peter and Georg Rich, 1992, “Monetary Policy Under Low Interest Rates: The Experience of Switzerland in the late 1970s,” Mimeo.

Lam, Raphael, 2011, “Bank of Japan’s Monetary Easing Measures: Are They Powerful and Comprehensive Enough?” IMF Working paper, forthcoming.

Laeven, Luc and Fabian Valencia, 2010, "Resolution of Banking Crises: The Good, the Bad, and the Ugly,” IMF Working Paper No. 10/146.

Lenza, Michele, Huw Pill, and Lucrezia Reichlin, 2010, “Monetary Policy in Exceptional Times,” ECB Working Paper No. 1253, October.

Liu, Philip, Haroon Mumtaz, and Konstantinos Theodoridis, 2011, "Changing Macroeconomic Dynamics at the Zero Lower Bound,” Mimeo, April.

Mackenzie, G. A. and Peter Stella, 1996, Quasi-Fiscal Operations of Public Financial Institutions, IMF Occasional Paper No. 142, October. 
Mancini Griffoli, Tommaso and Angelo Ranaldo, 2010, "Limits to Arbitrage During the Crisis: Funding Liquidity Constraints and Covered Interest Parity,” Swiss National Bank Working Papers 2010-14, June.

Martins, Guilherme B. and João M. Salles, 2010, “The Credit Dimension of Monetary Policy: Lessons from Developing Economies Under Sudden Stops,” Mimeo, November.

McAndrews, James, Asani Sarkar, and Zhenyu Wang, 2008, “The Effects of the Term Auction Facility On the London Inter-Bank Offered Rate,” Federal Reserve Bank of New York Staff Report No. 335, July.

Meier, André, 2009, “Panacea, Curse, or Nonevent? Unconventional Monetary Policy in the United Kingdom,” IMF Working Paper No. 09/163, August.

Mishkin, Frederic S., 2002, "From Monetary Targeting to Inflation Targeting: Lessons from the Industrialized Countries," in Banco de Mexico, Stabilization and Monetary Policy: The International Experience (Bank of Mexico: Mexico City): 99-139.

Moreno, Ramon, 2011, "Central Bank Instruments to Deal with the Effects of the Crisis On Emerging Market Economies,” in The Global Crisis and Financial Intermediation in Emerging Market Economies, BIS Paper No 54, January.

Neely, Christopher J., 2010, “The Large Scale Asset Purchases Had Large International Effects,” Federal Reserve Bank of St. Louis Working Paper 2010-018A, July.

Obstfeld, Maurice, Jay C. Shambaugh and Alan M. Taylor, 2009, "Financial Instability, Reserves, and Central Bank Swap Lines in the Panic of 2008," Paper presented at the ASSA Meetings, San Francisco, Jan. 3-5, 2009.

Oda, Nobuyuki, and Kazuo Ueda, 2007, “The Effects of the Bank of Japan’s Zero Interest Rate Commitment and Quantitative Monetary Easing on the Yield Curve: A Macro-Finance Approach,” Japanese Economic Review, 58(3), pp. 303-328.

Reinhart, Carmen and M. Belen Sbrancia, 2011, “The Liquidation of Government Debt,” NBER Working Paper 16893, March.

Reserve Bank of Australia, 2009, Annual Report, http://www.rba.gov.au/publications/annualreports/rba/2009/html/ops-fin-mkts.html.

Roger, Scott and Mark Stone, 2005, “On Target? The International Experience with Achieving Inflation Targets,” IMF Working Paper No. 05/163, August.

Romer, Christina. 1992. "What Ended the Great Depression?” Journal of Economic History, 52(4): 757-84. 
Romer, C. and D. Romer, 2000, "Federal Reserve Information and the Behavior of Interest Rates,” American Economic Review 90, issue 3, pp. 429-57.

Shirakawa, Masaaki, “Uniqueness or Similarity?- Japan’s Post-Bubble Experience in Monetary Policy Studies ,” 2010, Keynote Address at Second IJCB Fall Conference hosted by the Institute for Monetary and Economic Studies, the Bank of Japan, September.

Sorezcky, Avihay, 2010, “Did the Bank of Israel Influence the Exchange Rate?” Bank of Israel Research Department Discussion Paper No. 2010.10, October.

Stark, Jürgen, 2008, "Monetary, Fiscal and Financial Stability in Europe,” Speech at the 11th Euro Finance Week in Frankfurt, November 18.

Stella, Peter, 2008, “Central Bank Financial Strength, Policy Constraints and Inflation,” IMF Working Paper 08/49, February.

Stella, Peter, 2009, “The Federal Reserve System Balance Sheet: What Happened and Why it Matters,” IMF Working Paper 09/120, May.

Stella, Peter, 2010, “Minimising Monetary Policy,” BIS Working Paper No. 330, November.

Stone, Mark R. and Ashok Bhundia, 2004, “A New Taxonomy of Monetary Regimes,” IMF Working Paper No. 04/191, October.

Stone, Mark R., Scott Roger, Anna Nordstrom, Seiichi Shimizu, Turgut Kisinbay, Jorge Restrepo, 2009a, “The Role of the Exchange Rate in Inflation-Targeting Emerging Economies,” IMF Occasional Paper No. 267, November.

Stone, Mark, W. Christopher Walker, and Yosuke Yasui, 2009b, "From Lombard Street to Avenida Paulista: Foreign Exchange Liquidity Easing in Brazil in Response to the Global Shock of 2008-09,” IMF Working Paper No. 09/259, December.

Svensson, Lars E. O., 1997. "Inflation Forecast Targeting: Implementing and Monitoring Inflation Targets," European Economic Review, Vol. 41(6), pages 1111-1146, June.

Svensson, Lars. 2001. "The Zero Bound in an Open Economy: A Foolproof Way of Escaping from a Liquidity Trap.” Bank of Japan, Monetary and Economic Studies, 19(S-1), 277312, February.

Swiss National Bank, 2010, “Accountability Report 2009,” March.

Tarullo, Daniel K., 2010, “International Response to European Debt Problems,” Testimony Before the Subcommittee on International Monetary Policy and Trade and Subcommittee on Domestic Monetary Policy and Technology, Committee on Financial Services, U.S. House of Representatives, Washington, D.C. May 20. 
Taylor, John B. and John C. Williams, 2008, “Further Results on a Black Swan in the Money Market,” Stanford University, Mimeo, May.

Tobin, James, 1958. "Liquidity Preference as Behavior Towards Risk," Review of Economic Studies, vol. 25 (February), pp. 65-86.

Toma, Mark. 1992. “Interest Rate Controls: The United States in the 1940s.” Journal of Economic History, 52(3): 631-50.

Tucker, Paul, 2009, “The Repertoire of Official Sector Interventions in the Financial System: Last Resort Lending, Market-Making, and Capital,” Speech at the 2009 International Conference: Financial System and Monetary Policy Implementation, Bank of Japan, May 27-28.

Wallace, Neil, 1981, “A Modigliani-Miller Theorem for Open-Market Operations,” American Economic Review 71: 267-274.

Walsh, Carl, 2008, “Using Monetary Policy to Stabilize Economic Activity,” Paper presented at the 2008,” Federal Reserve Bank of Kansas City, Symposium at Jackson Hole.

Wilkes, Giles, 2010, “Credit Where It's Due: Making QE Work for the Real Economy,” Centre Forum, http://www.centreforum.org/publications/credit-where-its-due.html.

Wu, Tao, 2010, “The U.S. Money Market and the Term Auction Facility in Financial Crisis of 2007-2009,” Review of Economics and Statistics, forthcoming. 
Figure 1. Accumulated Balance Sheet Changes, Major Central Banks

(In percent of GDP)
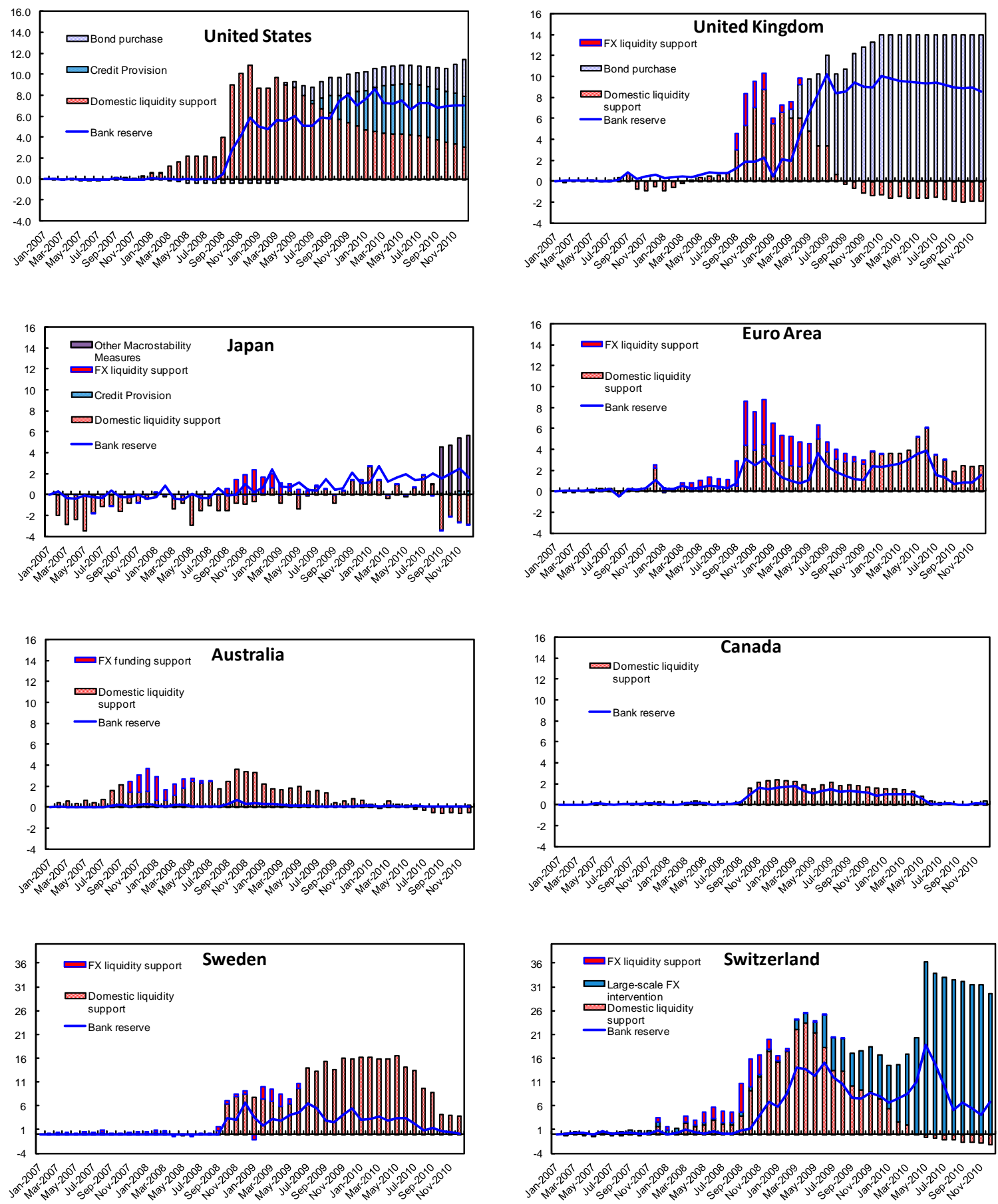

$$
\begin{array}{ll}
\text { Large-scale FX intervention } & \text { FX liquidity support } \\
\equiv \text { Credit provision } & \text { Domestic liquidity support } \\
\text { Bond purchase } & \text { Bank reserve }
\end{array}
$$


Figure 2. Maturing and Collateral Composition of Liquidity Support, Reserve Bank of Australia

(January 2007-September 2009)

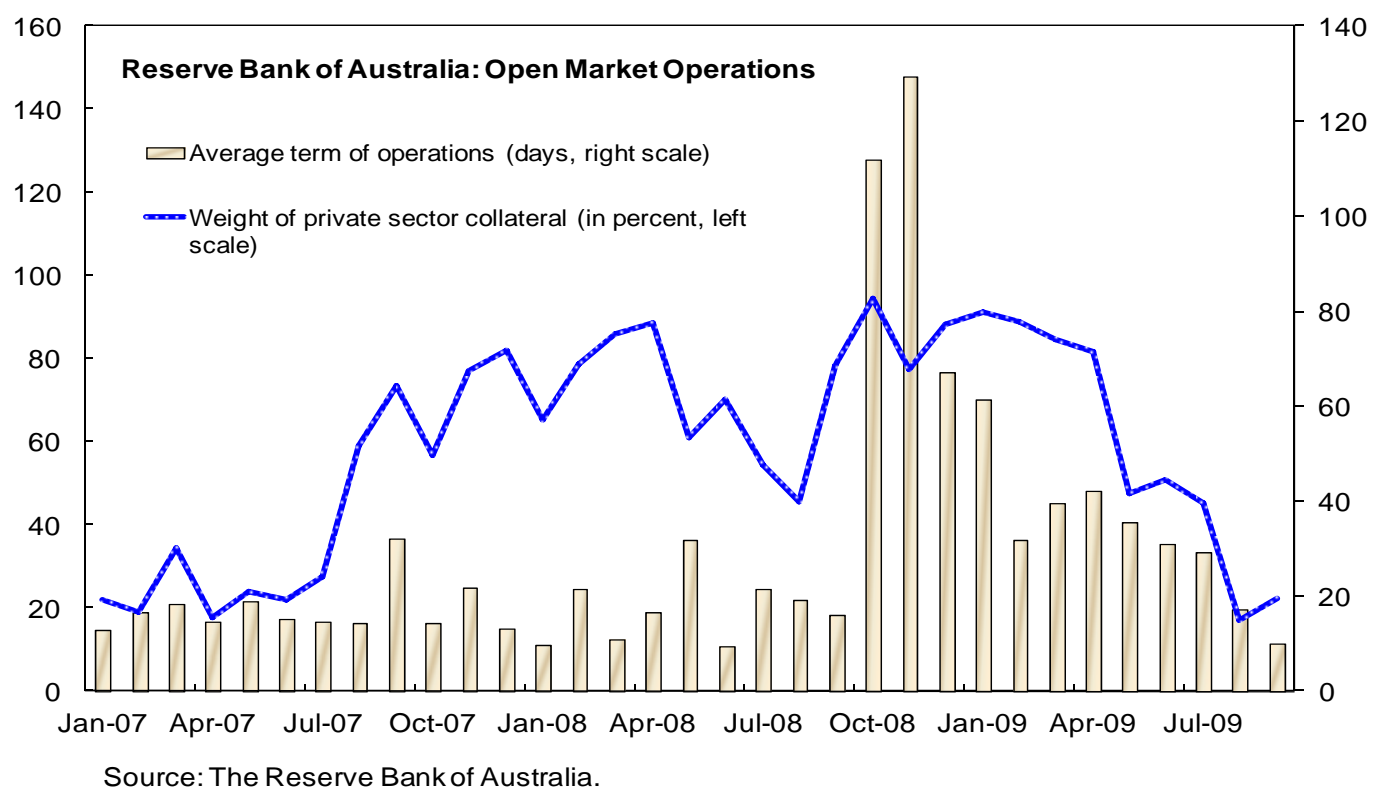

Figure 3. Liquidity Support to Domestic Funding (In percent of GDP)

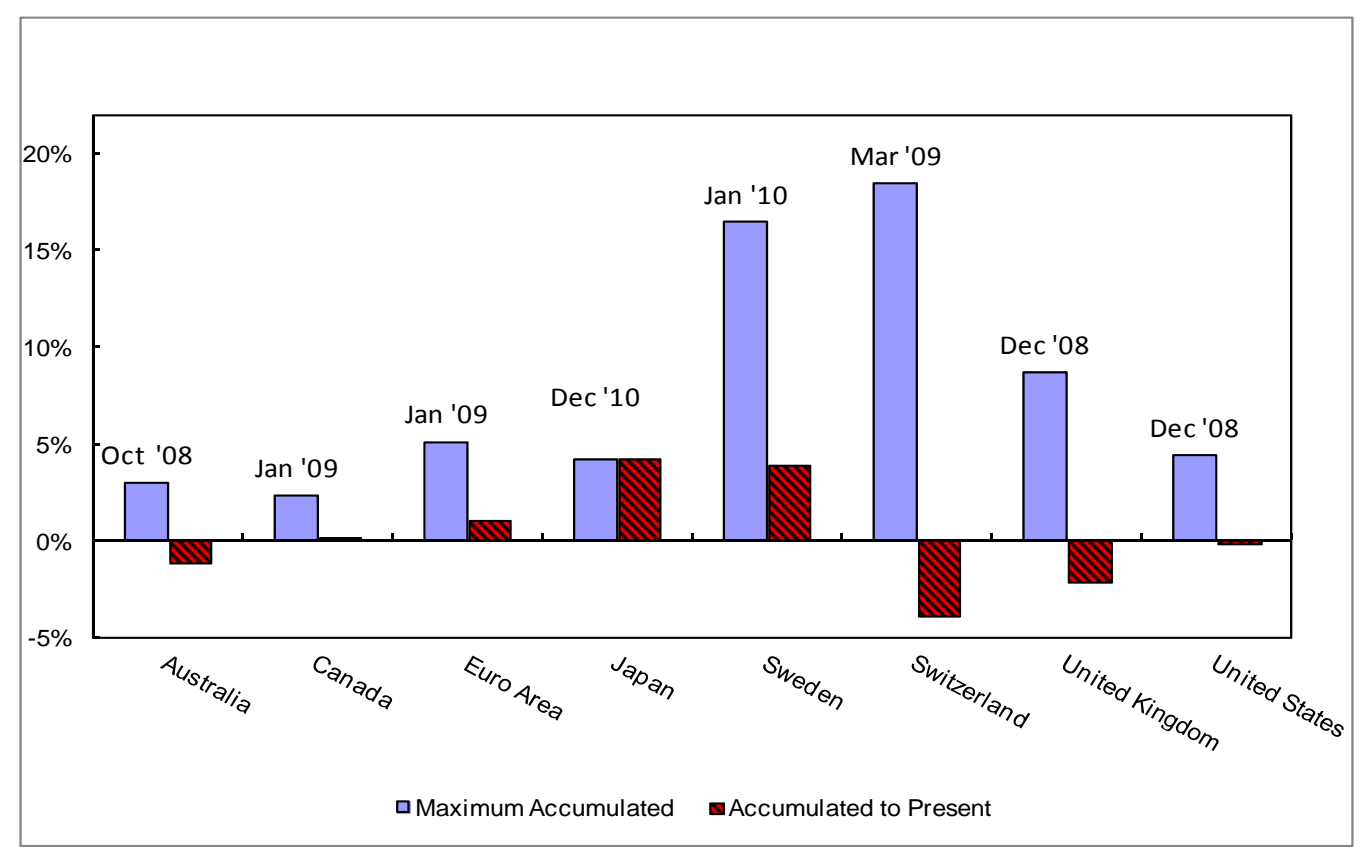


Figure 4. Liquidity Support to Domestic Credit Markets (In percent of GDP)

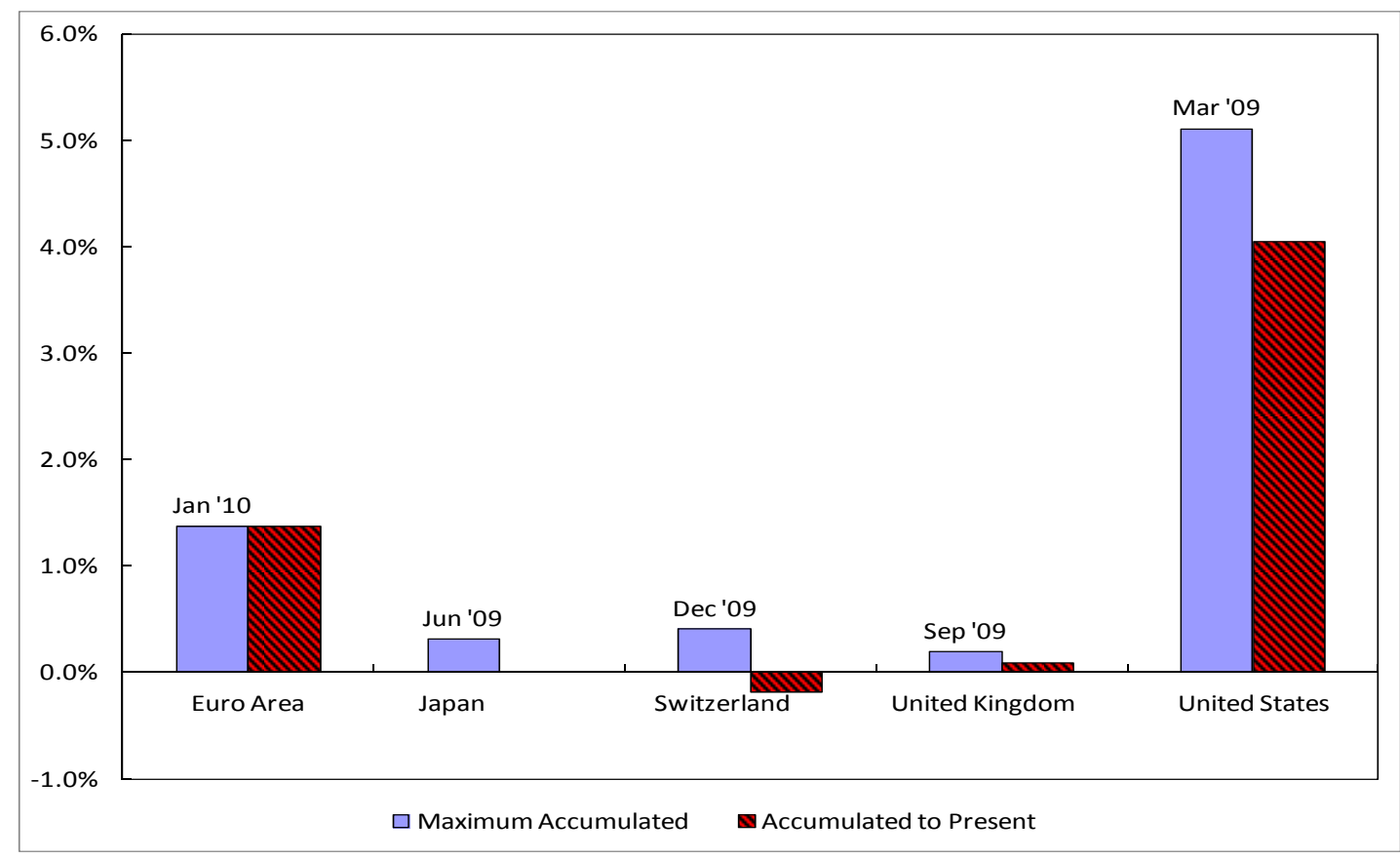

Figure 5. Maximum TED Spread and Maximum Domestic Market Support (In percentage points and percent of GDP)

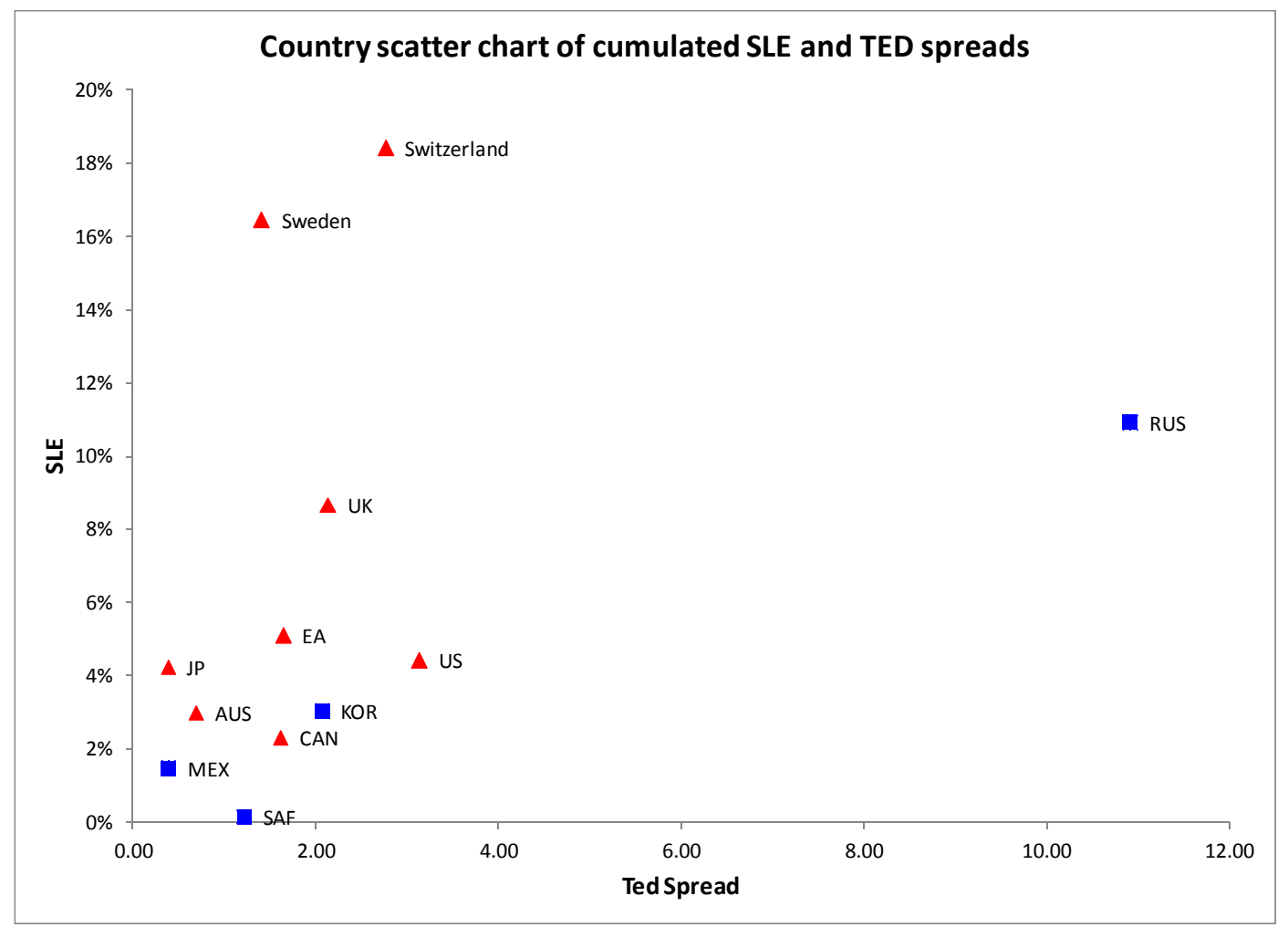


Figure 6. The Maximum Amount of Bilateral Swaps with the Fed

(In percent of GDP)

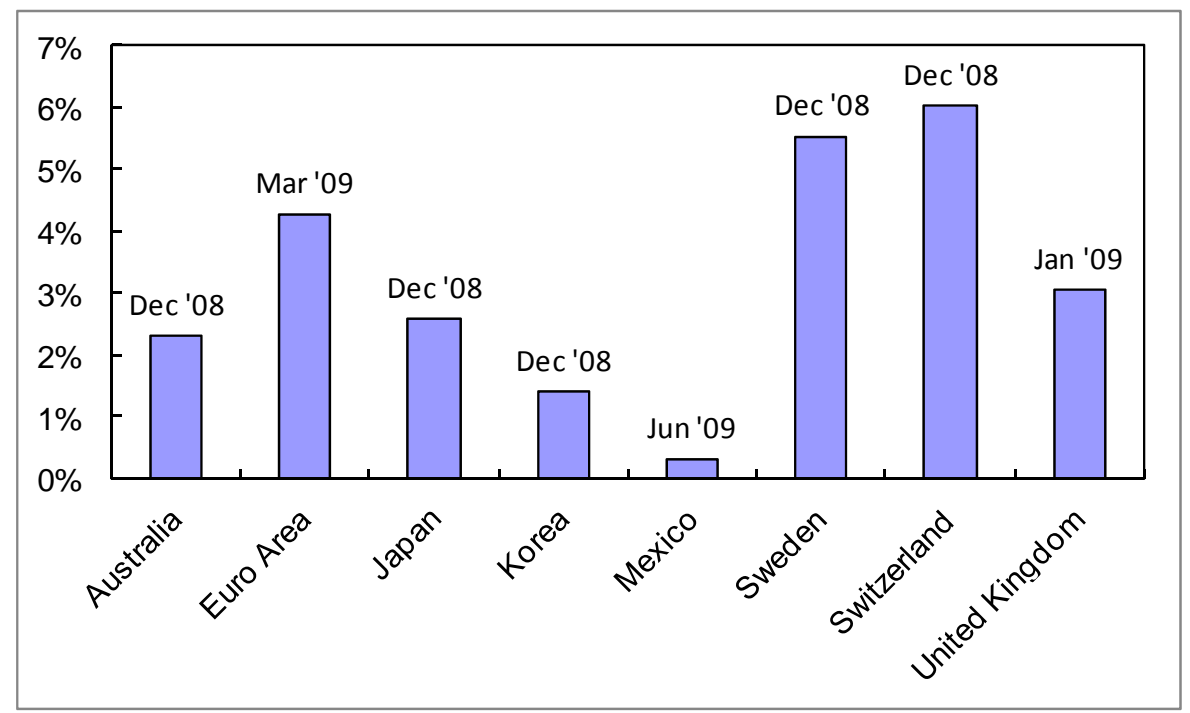

Figure 7. Selected Central Banks, Terms of Foreign Exchange Liquidity Provision Sourced from the Federal Reserve

(December 2007-February 2010)

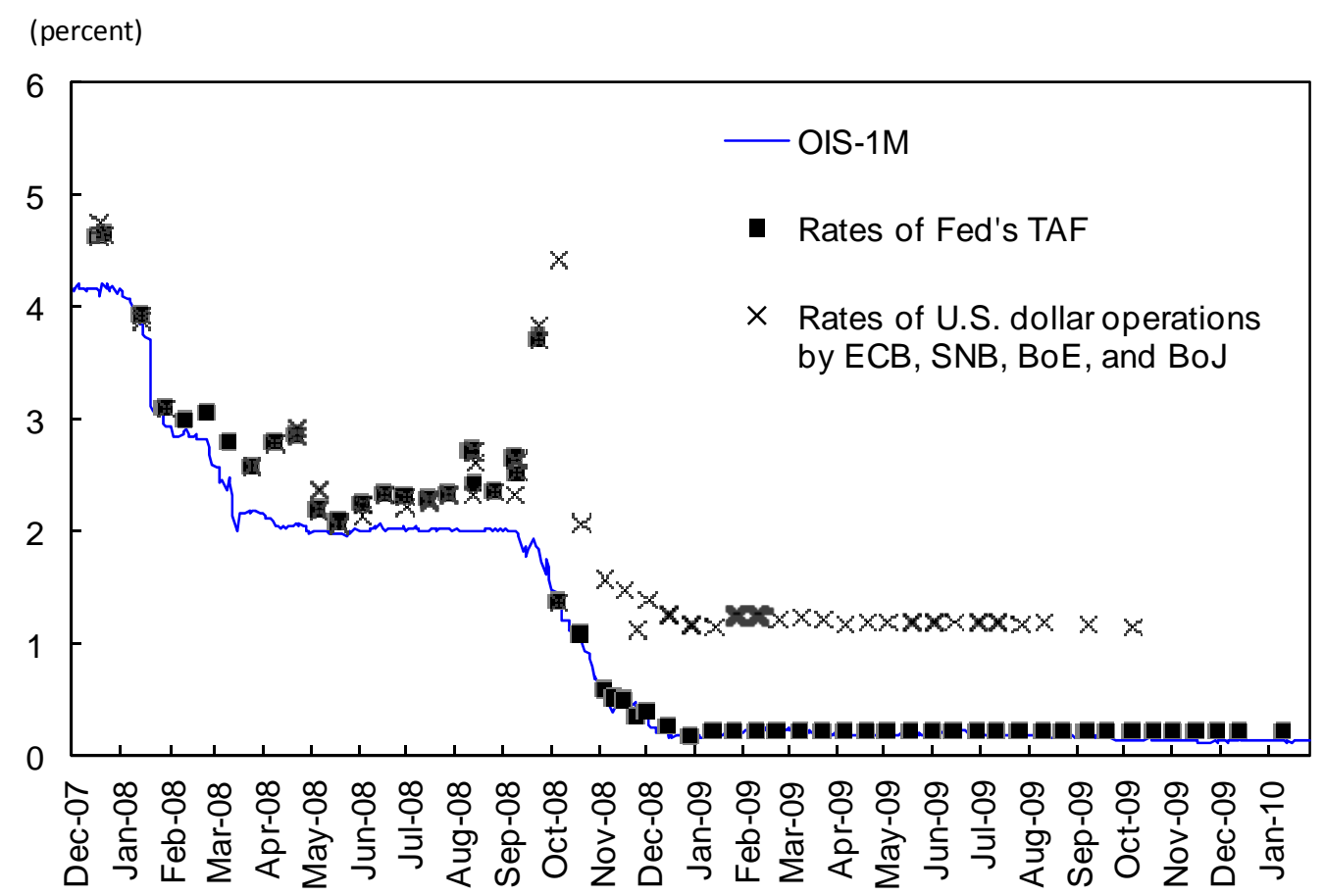


Figure 8. Selected Countries, Policy Interest Rates

(January 2007-December 2010)
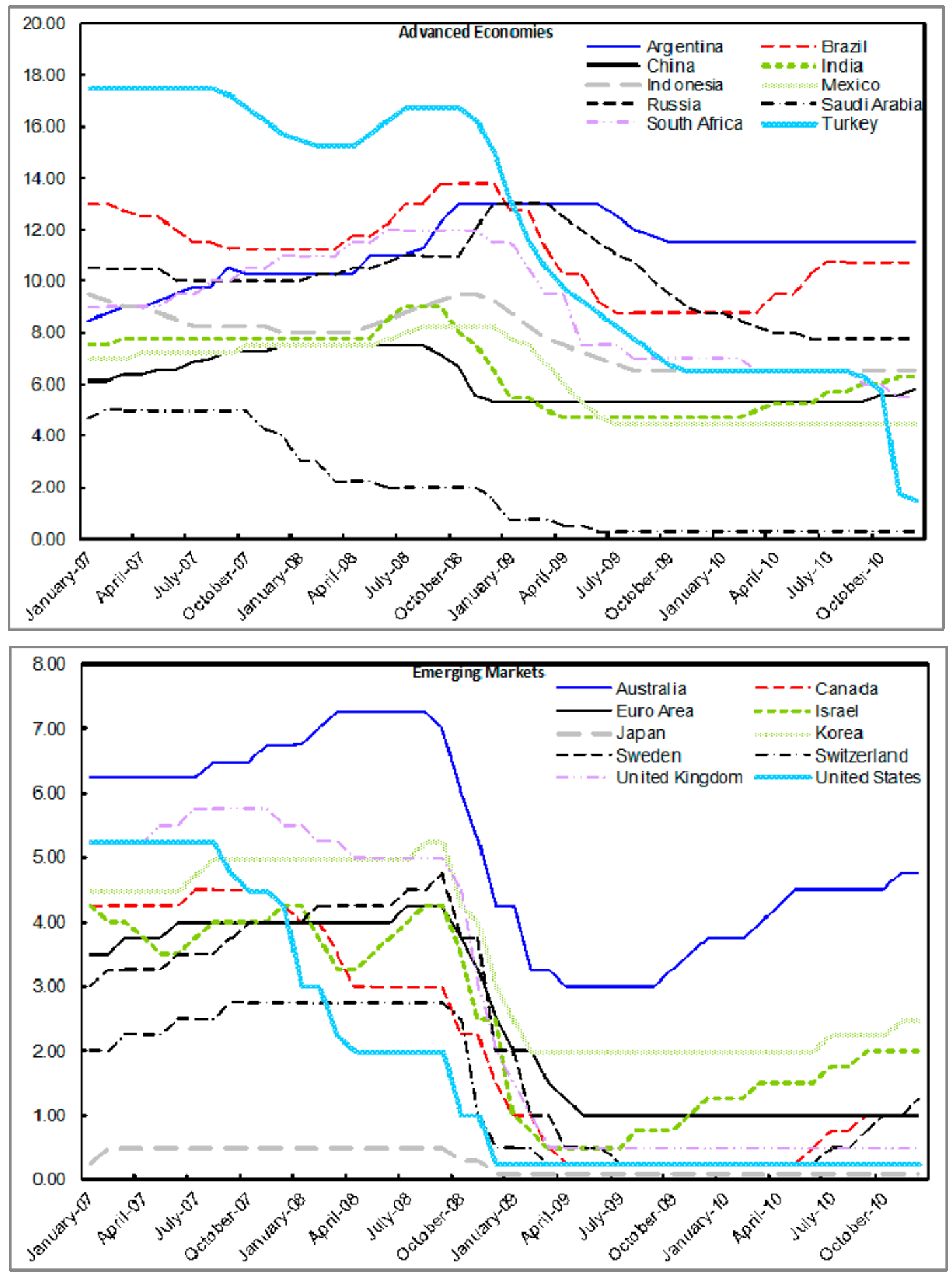
Figure 9. Bond Purchases and Policy Interest Rates
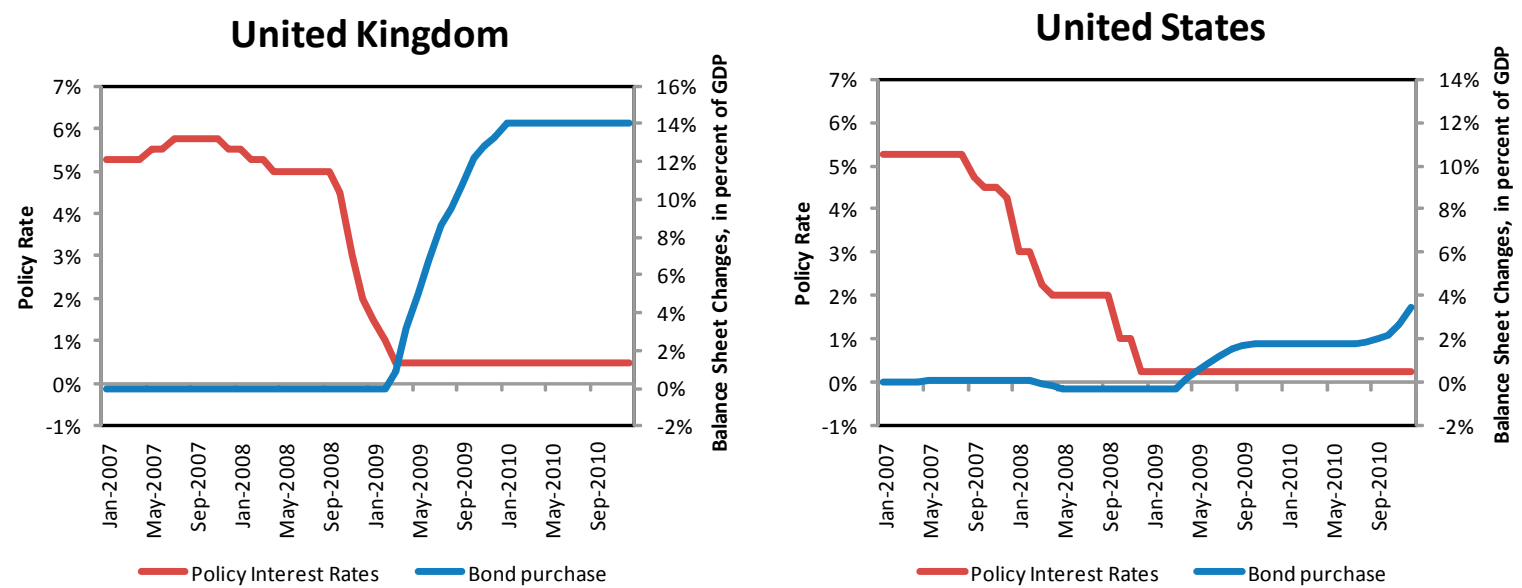

Figure 10. Holders of Public Securities, Stocks

(In percent of GDP)
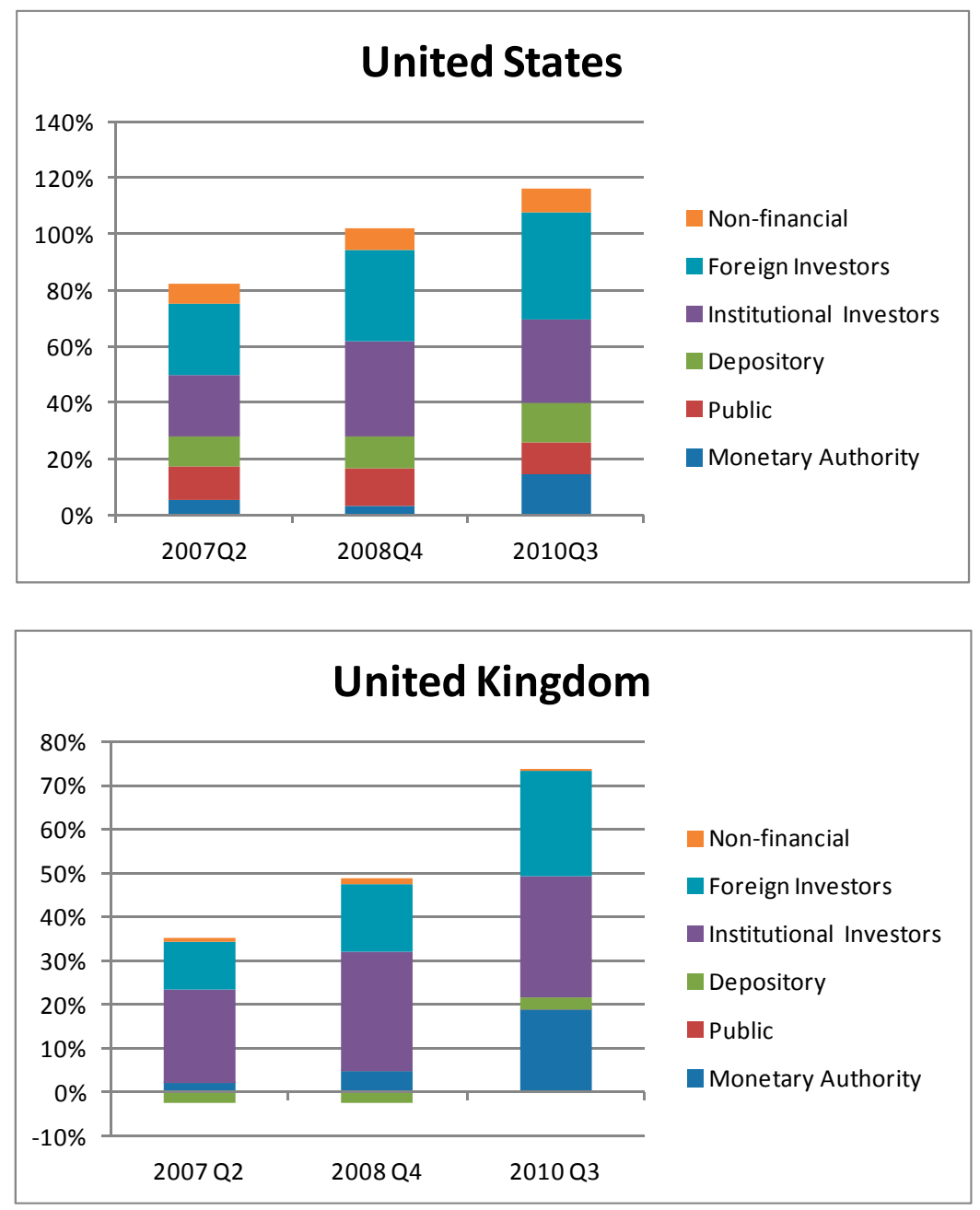
Figure 11. Holders of Public Securities, Flows

\section{(In percent of GDP)}
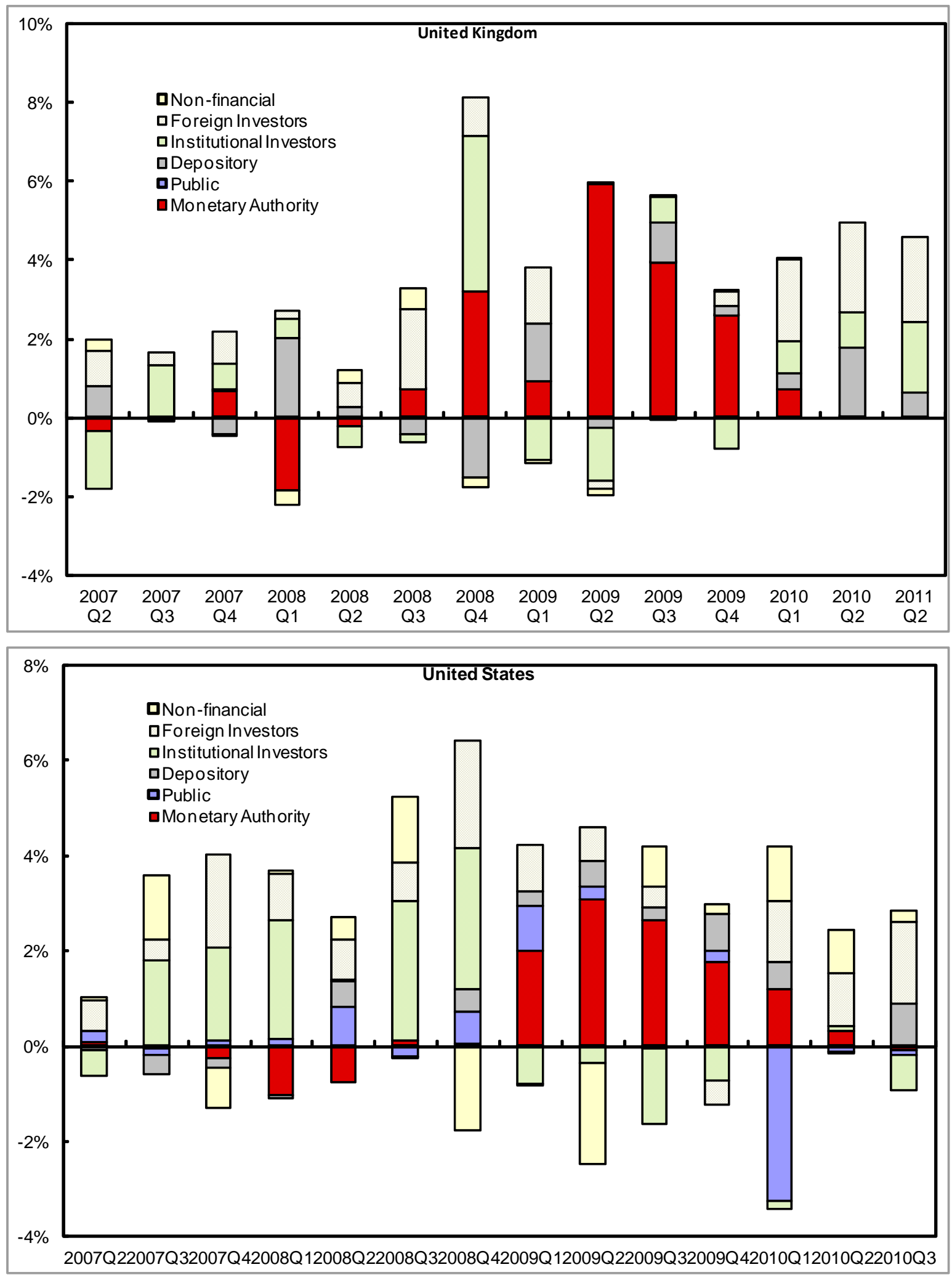
Figure 12. Exchange Rate, Policy Interest Rate, and Foreign Exchange Purchases (In percent of GDP)

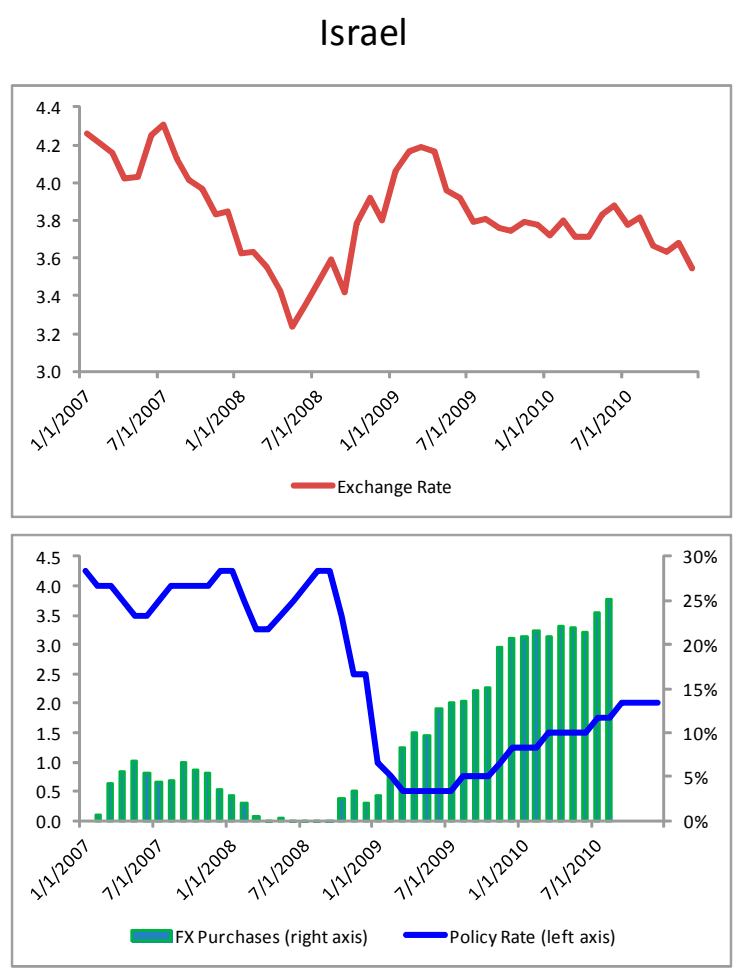

Switzerland
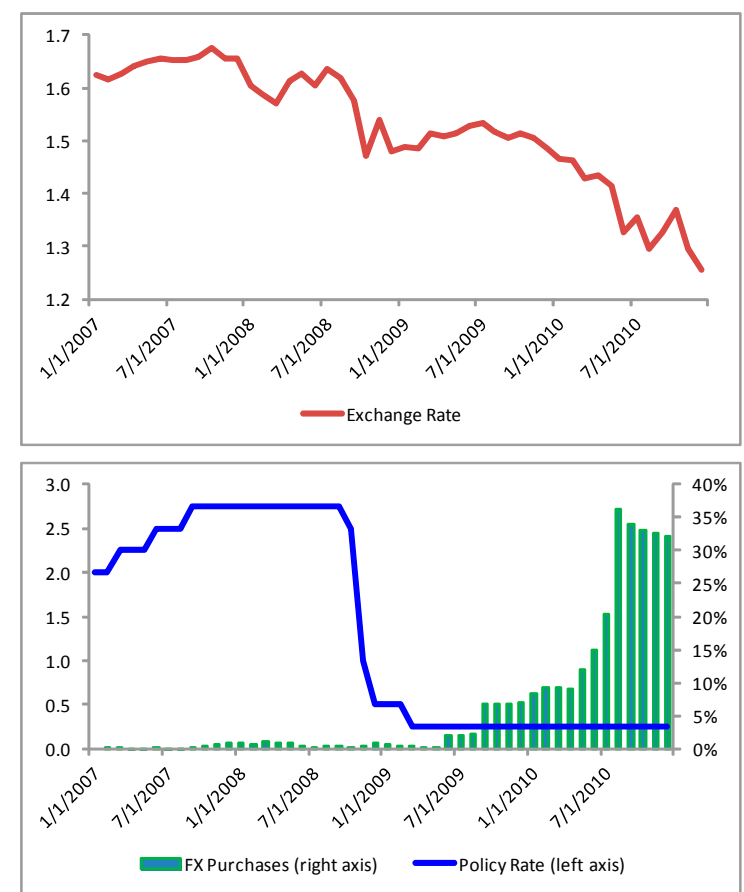


\section{APPENDIX I. CENTRAL BANK LIQUIDITY SUPPORT FOR INDIVIDUAL FINANCIAL INSTITUTIONS DURING THE RECENT CRISIS}

106. During the recent crisis period, several major central banks extended liquidity support for individual financial institutions. These were to prevent a disorder failure of systematically important financial institution from causing serious harm to the economy. This support is a time-honored tool of central banks going back to the $19^{\text {th }}$ century or earlier. This policy rests on the ability of the central bank to generate reserve money as well as its informational advantage allowing it to judge that an individual institution is illiquid rather than insolvent (the latter is a fiscal responsibility) and that its failure could have systemic consequences and thus requires public support.

107. A few countries provided significant amount of liquidity support for individual financial institutions during the recent crisis. The BoE and SNB extended emergency loans to banks, the traditional recipients of emergency liquidity support. The Fed provided liquidity support to non-bank financial institutions, which are more atypical for the central bank. The liquidity support extended by BoE has already been repaid and that by the Fed and SNB have been decreased gradually.

108. As those loans pose a potential high credit risk, central banks protected their balance sheets in various ways. The emergency loans extended to specific institutions during the recent crisis have all been collateralized. The UK government provided lossprotection and in the U.S. and Switzerland private institutions committed to take certain amount of first losses.

109. Preventing moral hazard is an important element in designing those loans. A traditional approach to prevent moral hazard is to extend loans at a penalty rate. All the liquidity support extended to specific institutions during the crisis period was at higher than the market rates. The Fed provided controversial liquidity support to American International Group and at the same time "worked with AIG to replace its management.”

110. The timing and elements of disclosure of those loans have differed across the cases, largely depending on the possible impacts on the markets' confidence on the conditions of the troubled institution. The BoE delayed the disclosure of the terms and conditions, or even the names of the recipient of the loan, when the bank extended emergency loans to ongoing entities (Royal Bank of Scotland and HBOS). When the liquidity-receiving institution is under public resolution scheme or when the disclosure of emergency credit extension could buttress the confidence to the institution, there would be no reason to hold back the information (the Fed and SNB).

\section{In general, the liquidity support to troubled institutions seems to have helped} forestall systemic stress (Figure 13). In two out of four cases in which the liquidity support was announced immediately, the stress in interbank markets seemed to be alleviated after the announcement. For other two cases, the effectiveness of the liquidity support is hard to measures as those two cases occurred in the middle of the severe stress following the collapse of Lehman Brothers. 
Figure 13. Changes of Libor-OIS Spreads from the Event Day ${ }^{1 /}$

\section{(Basis Point)}

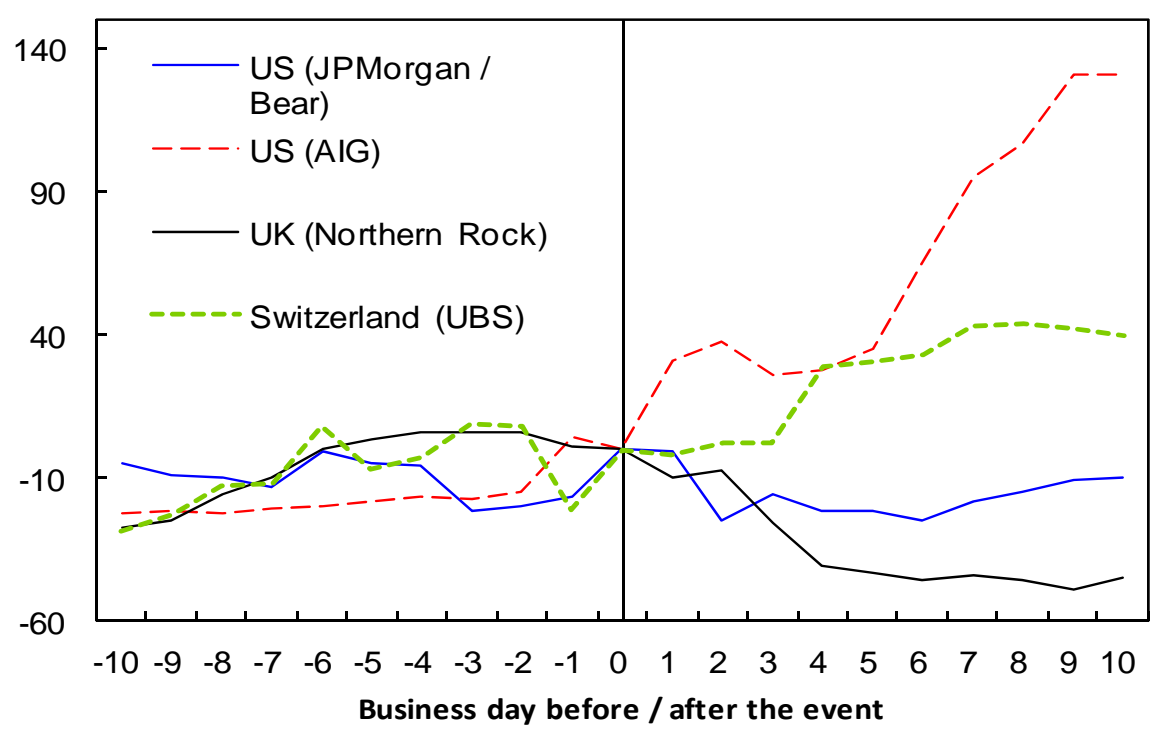

1/ The event day for each case of liquidity support are as follows: September 17, 2007 for Northern Rock, March 16, 2008 for JP Morgan / Bear Stears, September 16, 2008 for AIG, and October 16, 2008 for UBS. 


\section{Appendix II. UnRaveling Financial Risks of Bond PURCHASE}

\section{While bond purchases seem to have lowered yield curves on impact, the effects} do not come without costs. Central bank bond purchases generate a maturity mismatch between large amounts of long-term assets and short-term liabilities. This makes the balance sheet vulnerable to increases in interest rates. Further, bond purchases shorten the duration of the liabilities of the consolidated public sector balance sheet, which could increase ex-post public financing costs in the case of unexpected rises in interest rates.

\section{The impact of bond purchases on the financial position of the central bank}

\section{A central bank can incur financial losses from bond purchase depending on its exit strategy and accounting practices:}

- $\quad$ Income loss - the central bank raises the policy rate and its interest expenses exceed income gains from purchased bonds.

- $\quad$ Capital loss - the central bank sells outright the purchased bonds at a price lower than the purchase price.

- $\quad$ Valuation loss - the central bank values the purchased bonds at fair value, and an increase in interest rates lower the value of the bonds.

\section{Financial losses can deplete central bank capital and threaten monetary policy} autonomy. If losses caused by bond purchases substantially reduce the capital base of the central bank, leaving it dependent on fiscal authorities for funding its expenses, the autonomy of monetary policy could be threatened. This threat to autonomy can be countered by a capital injection. In order to safeguard central bank independence, the gross amount of loss per se matters less than the impact on the capital base. Therefore, if expected losses-which could be computed by a prevailing methodology such as VAR or sensitivity analysis - are smaller than other expected income or capital base, the risks may not be of great concern. ${ }^{37}$ If the expected loss is relatively large, an explicit and ex ante agreement between central bank and government to secure central bank capital base-agreement to transfer materialized losses or to restore the depleted capital—would be needed to assure monetary policy autonomy.

\section{The impact of bond purchases on the consolidated public balance sheet}

\section{Central bank bond purchases shorten the maturity of the consolidated public} sector liabilities by replacing outstanding long-term bonds with short-term debts (Figure 14). The effect of central bank bond purchases on a consolidated public balance sheet is identical with that of debt management strategy to replace long-term bonds with T-bills

\footnotetext{
${ }^{37}$ Kohn (2009) argued that the risk that the interest rates expenses of the Fed would outweigh the interest earnings from long-term securities is unlikely.
} 
("short-funding strategy", Figure 14). Hence financial losses incurred by central banks from bond purchase can be viewed as the same as increases in public financing costs when the "short-funding strategy" backfires:

- Income loss - central bank income losses from a policy interest rate hikes mirror an increase in public financing costs caused by increases in short-term interest rates from a debt management "short-funding strategy."

- $\quad$ Capital loss - central bank outright sales of purchased bonds at a loss mirror an increase in public financing costs from the debt manager unwinding a "short-funding strategy” (reissues long-term bonds) when long-term rates are high.

- Valuation loss - in contrast, a valuation loss does not generate a loss for the consolidated public balance sheet as a valuation loss on the asset side of the central bank is cancelled out by a corresponding gain on the liability side of the government.

116. Another dimension of risks of bond purchase is increased refinancing (rollover) risk due to effective shortening of debt maturity on a consolidated basis. In general, as the debt maturity becomes shorter, the debtor is more likely to face refinancing risks in the event that its solvency is questioned by the market. Of course, a central bank may not face the refinancing risk in a technical sense, as they can issue legal tender that has finality in the payment system. However, the holders of public debts - either those issued by the government or the central bank - may require higher premium or convert them to other currencies, that could make it increasingly difficult and costly to repay those debts. The shorter is the debt maturity, the more vulnerable to such pressures is the debtor.

\section{Central bank bond purchases should be driven by its contributions to stable} macroeconomic conditions. Bond purchases may increase public financing costs as described above, or decrease them-reduced yield curves during the conduct of bond purchase as well as possible increase in tax revenue due to economic recovery. These effects should be, however, viewed as secondary to the monetary policy objective. ${ }^{38}$

118. The bond purchase by the Fed and the $\mathrm{BoE}$ is estimated to somewhat reduce the maturity of the consolidated sovereign debt (Figure 15). This estimate is made by: (i) constructing the list of outstanding securities of the consolidated sovereign ${ }^{39}$ by replacing the

\footnotetext{
${ }^{38}$ Bean (2009) suggests that BoE initiated the Quantitative Easing to achieve the Bank's macroeconomic objectives-hitting the inflation target without generating undue volatility in output--, while acknowledging the program could have certain impacts on public financing costs.

${ }^{39}$ The estimate of the U.S. figure after "QE2" requires assumptions on (i) the list of the securities the Fed will purchase by June 2011 and (ii) the base line list of outstanding government securities in 2011. For (i), the Fed is assumed to purchase the government securities in line with the maturity composition disclosed at the website of the Federal Reserve Bank of New York (http://www.newyorkfed.org/markets/opolicy/operating_policy_101103.html). For (ii), the U.S. Federal debt held by the public is assumed to be 69.3 percent of GDP in 2011 based on Celasun and Keim (2010).
} 
Gilts the BoE purchased or the U.S. Treasury Securities the Fed is expected to purchase with short-term debts, and (ii) computing the average maturity of this estimate of consolidated public sector debt. The BoE's Quantitative Easing (GBP200 billion Gilts purchase from March 2009 to June 2010) is estimated to have reduced the average debt maturity of the U.K. public sector by two years . The Fed's so-called QE2 (\$600 billion purchase of U.S. Treasury from November 2010 to June 2011), ${ }^{40}$ is estimated to have reduced the average debt maturity of the U.S. public sector by six months.

\footnotetext{
${ }^{40}$ We exclude the effect of “QE1” which comprised \$1.25 trillion of GSE-backed MBS, \$175 billion of GSE debts, and $\$ 300$ billion of U.S. Treasury for the following reasons: first, including GSE-related securities, in particular GSE-backed securities which consist of claims on private debtors and contingent claim on GSEs, would extremely complicate the computation. Second, as the Fed holdings of treasury securities after the "QE1" was almost the same level as pre-crisis, it would not be appropriate to argue that the Fed's crisis-response measures including "QE1" shortened the maturity of the public sector debt.
} 
Figure 14. Stylized Balance Sheet-Central Bank, Government, and Consolidated Sovereign

\section{Original State}

- The government issued 70 long-term bonds.

- The central bank has issued 20 banknotes and10 bank reserves under a reserve requirement system, and the liquidity is provided through 30 open market operations.

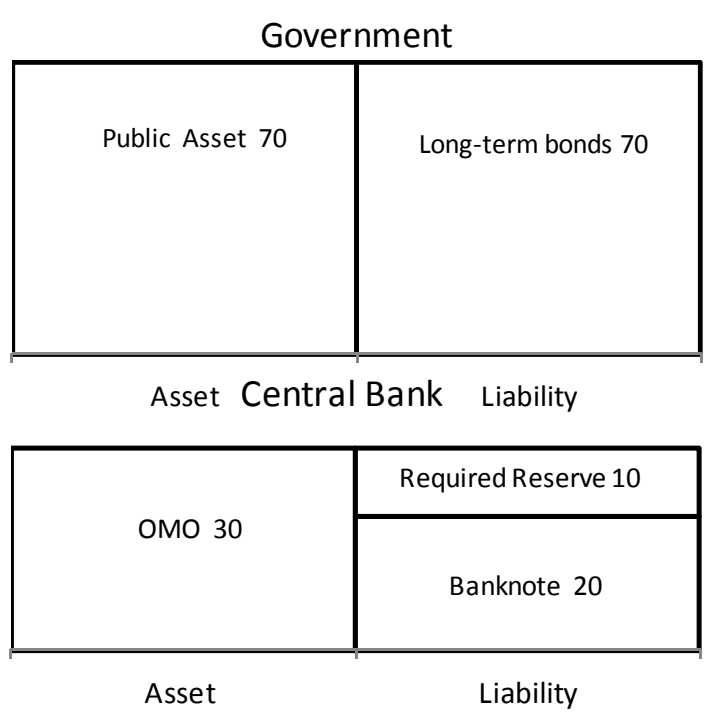

\section{After Bond Purchase}

- The central bank purchased 20 long-term bonds from the private sector, with having the same amount of excess reserves as the counterpart.

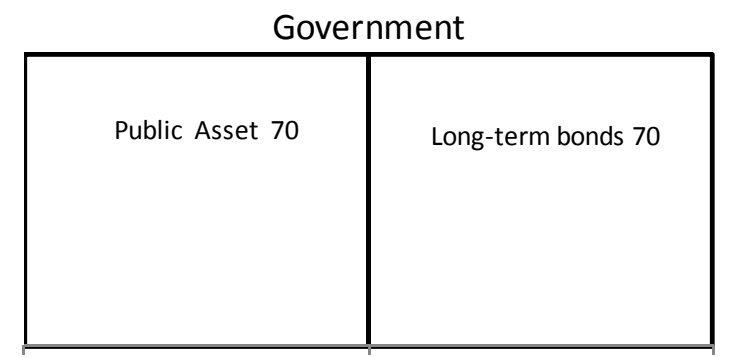

Asset Central Bank Liability

\begin{tabular}{|c|c|}
\hline Long-term bonds 20 & Excess Reserve 20 \\
\hline OMO 30 & Required Reserve 10 \\
\cline { 2 - 2 } & Banknote 20 \\
\hline Asset & Liability \\
\hline
\end{tabular}

- When consolidated, the sovereign has 70 long-term debts and 30 non-interest bearing debts.

\section{Consolidated Soverign}

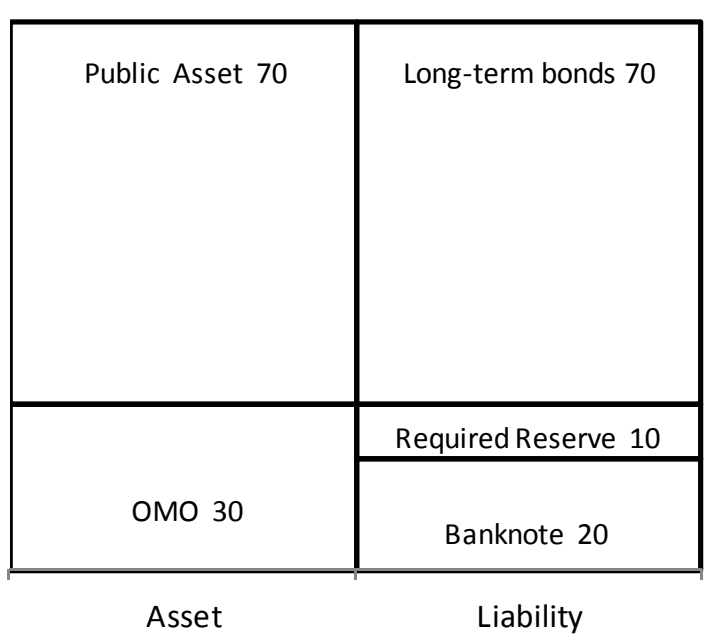

- When consolidated, the central bank's holdings of 20 long-term bonds are canceled out with the government's issuance of the same amount of bonds.

- This leaves 50 long-term debts, 20 short-term interest bearing debts (excess reserves), and 30 non-interest bearing debts.

\section{Conslidated Sovereign}

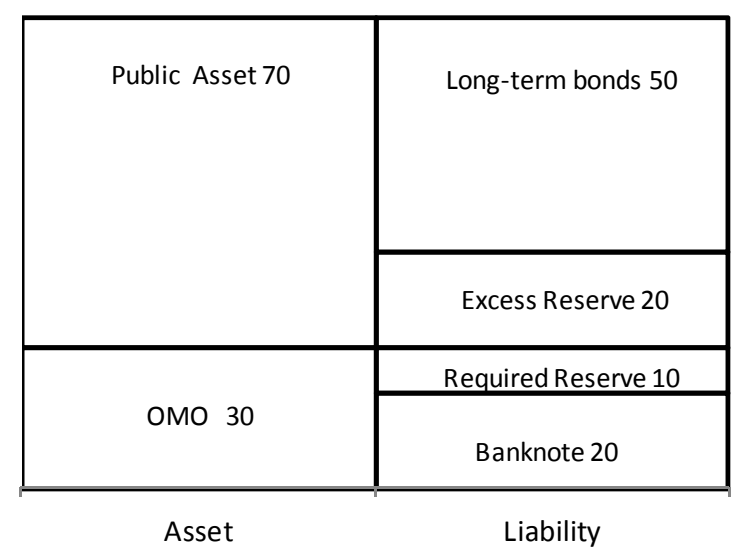


Figure 14. Stylized Balance Sheet—Central Bank, Government, and Consolidated Sovereign (continued)

"Short-funding Strategy" by the Government

- Alternatively, the government can buy back 20 long-term bonds and issue the same amount of T-bills.

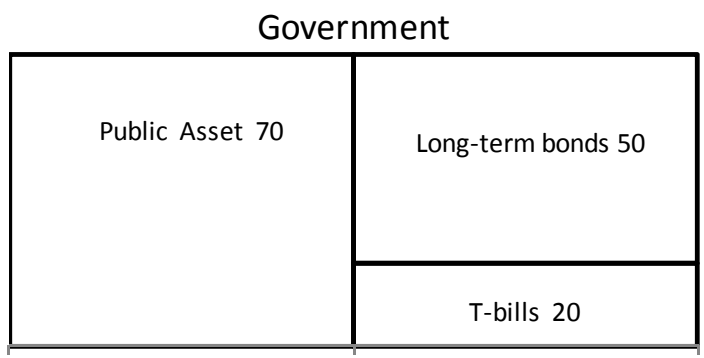

Central Bank

\begin{tabular}{|c|c|}
\hline \multirow{2}{*}{ OMO 30 } & Required Reserve 10 \\
\cline { 2 - 2 } & Banknote 20 \\
\hline
\end{tabular}

Asset
- When consolidated, the sovereign has 50 long-term debts, 20 short-term interest bearing debts (T-bills), and 30 non-interest bearing debts-the same balance sheet structure as one after bond purchase.

\begin{tabular}{|c|c|}
\hline Conslidated Sovereign \\
\hline Public Asset 70 & Long-term bonds 50 \\
\cline { 2 - 2 } & T-bills 20 \\
\hline OMO 30 & Required Reserve 10 \\
\cline { 2 - 2 } & Banknote 20 \\
\hline Asset & Liability \\
\hline
\end{tabular}


Figure 15. Estimated Maturity of Consolidated Sovereign Debt
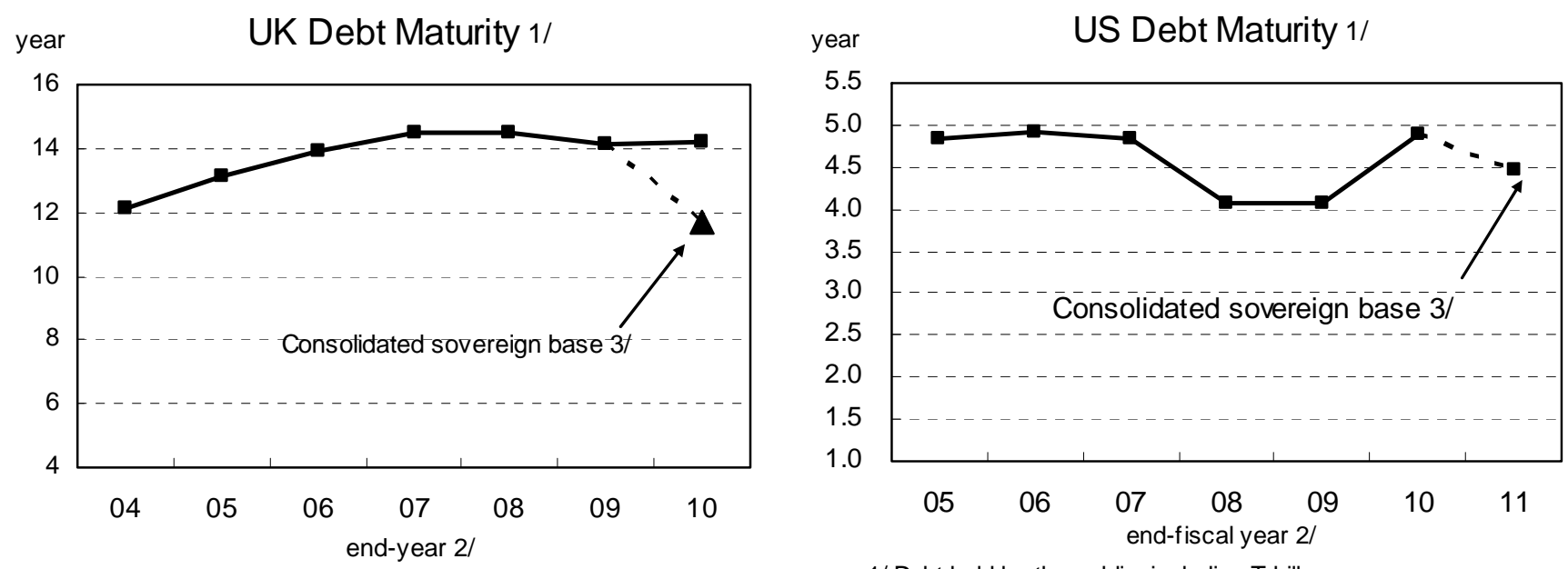

1/ Excluding T-bills.

$1 /$ Debt held by the public, including T-bills.

2/ The figure for 2010 is that on October 31.

$3 /$ The "consolidated sovereign" figure is computed by assuming that the maturity of the liabilities the Fed would have as a counterpart of US Treasury purchased for QE2 is 1 month. that the maturity of liabilities of the Asset Purchase Facility is 1 month. 


\section{ApPENdiX III. Best PRACTICES}

119. This appendix elaborates what can be viewed as the best practices of balance sheet policy implementation. Unconventional policies are different in key respects from conventional policies. Thus, establishing best practices for balance sheet policies would be useful to enhance their effectiveness by promoting public understanding of what they aim to achieve, articulating the central bank’s policy choices and considerations, and reducing uncertainties in decision making. They are also meant to help ensure central bank independence and accountability in monetary policy.

\section{A. Objectives, Transparency, and Accountability}

1. The objectives and broad framework of balance sheet policies should be clearly set out in terms of the central bank policy mandate.

120. The objectives of balance sheet policies should be consistent with ultimate objectives of the central bank, such as price, macroeconomic, and financial stability. A clear statement of the objectives and operational framework of balance sheet policies helps avoid actual or perceived ad hoc changes to the fundamental priorities of a central bank. Further, explanation of the rational for introducing balance sheet policies, potential risks and risk management measures facilitates transparency by allowing outcomes to be compared with goals, and thus allowing central banks to be held accountable.

\section{Best practices}

- General views of central banks - Senior officials of several central banks that leaned heavily on balance sheet policies made speeches spelling out the objectives and other aspects of their balance sheet policy frameworks (e.g., Bernanke (Fed), April 2009, Smaghi (ECB), April 2009, Trichet (ECB), July 2009, King (BoE), January 2009, and Nishimura (BoJ), October 2010)

- $\quad$ Financial stability balance sheet policies:

- $\quad$ Liquidity provision to domestic interbank and credit markets-Many of these measures were announced in a way that distinguished them from changes in monetary policy stance. The Fed's description of the Term Auction Facility (in December 2007), the Primary Dealer Credit Facility (March 2008), the Asset-Backed Commercial Paper Money Market Mutual Fund Liquidity Facility (September 2008), the Commercial Paper Funding Facility (October 2008), specified that these were to "help foster improved conditions in financial markets more generally.” The ECB's covered bond purchase program of May 2009 was "to support a specific financial market segment that is important for the funding of banks and that had been particularly affected by the financial crisis," and its Securities Markets Program in May 2010 "to address the malfunctioning of securities markets and restore an appropriate monetary policy transmission mechanism.”

- $\quad$ Liquidity provision to domestic foreign exchange markets-The BoC, the BoE, the ECB, the SNB, and the Riksbank's term dollar liquidity facilities 
introduced in December 2007 were "to address elevated pressures in short-term funding markets.”

- Macroeconomic stability balance sheet policies:

- $\quad$ Bond purchases - The Fed in March 2009 introduced a program to purchase longer-term Treasury securities to help improve conditions in private credit markets. The BOE in March 2009 announced the introduction of an Asset Purchase Facility, as "an additional tool that the Monetary Policy Committee (MPC) could use for monetary policy purposes.”

- $\quad$ Support to credit - The Fed in November 2008 introduced a program to purchase agency debts and MBSs "to reduce the cost and increase the availability of credit for the purchase of houses, which in turn should support housing markets and foster improved conditions in financial markets more general.” The BOJ in October 2010 introduced "comprehensive monetary easing” measures, including a private sector asset purchase program, "to encourage the decline in risk premiums."

2. The central banks should explain to the extent possible the expected transmission mechanism and risks of balance sheet policies.

121. In comparison with conventional central bank policies, the public is largely unfamiliar with many aspects of unconventional balance sheet policies and transmission is not well understood and highly uncertain. Further, the central bank needs to explain the expected risks of the policies because, as some of balance sheet policies could involve much larger financial risks compared to conventional monetary policy, distortional effects in the markets, and moral hazard with respect to financial institutions and market players. Accordingly, in implementing balance sheet policies, the central bank should explain the policy objectives, as well as the key expected transmission mechanisms including indicators for the appraisal of policy effectiveness.

\section{Best practices}

- In many cases, central banks explained thoroughly how balance sheet policies were expected to contribute to the economy. These explanations have been conducted in various vehicles such as by pamphlet (e.g., BOE’s "Quantitative Easing Explained"); speeches by senior central bank officials (e.g., Fed Chairman Bernanke's speech at Jackson Hole annual meetings in August 2010 about the Fed's purchases of long-term securities and BOE Deputy Governor Bean's speech about quantitative easing); testimony before lawmakers (e.g., Fed Chairman Bernanke's testimony before a U.S. Senate committee in July 2010, and BOJ's semiannual report to the Diet); and, analytical reports (BOE Working Paper, The Financial Market Impact of Quantitative Easing).

- When conducting measures involving larger credit risks than regular operations, most central banks explained how these risks should be managed. The Fed explained its $\underline{\text { over risk management framework and provided further details on its } \underline{\text { CPFF }} \text { and TALF }}$ 
facilities. The BoJ also published its risk management measures: for example, see “Outright Purchases of Corporate Financing Instruments (January 22, 2009).”

3. The central banks should make public the details of the operational design of balance sheet operations, including the terms and conditions of auctions and their actual use.

122. The disclosure of the operational details of balance sheet policies, not only to counterparties but also to the general public, can improve understanding of the objectives, the transmission mechanisms, and the risks of the measures. This information should include a financial statement of assets and liabilities that include specific items from balance sheet policies, auction results of balance sheet policy operations, and outstanding of these operations, by types, maturity, and risk profiles.

\section{Best practices}

- In most cases, key operational features of balance sheet policies (e.g., eligible counterparties, eligible instruments including credit requirements and maturity, pricing including auction mechanisms and collateral margins, frequency of operations) were disclosed to the public. Central banks have disclosed key operational features of unusual operations introduced during the crisis period: see, for example, the case of the Fed, BoE, BoJ, and the Riksbank

4. The central banks should periodically explain progress in achieving policy objectives through balance sheet policies.

123. In light of the unfamiliarity and conditionality of balance sheet policies, central banks should provide the assessment, including progress in achieving the main objectives, their challenges, and prospects for exit strategies. This provides useful information for the market and the general public to assess the performance of the central banks.

\section{Best practices}

- $\quad$ The Fed provided analysis on the effectiveness of their balance sheet measures in several occasions, including in its monetary policy report to Congress, senior officials' speeches (e.g., Fed Chairman Bernanke’s speech on October 15, 2010), and congressional testimony (e.g., Fed Chairman Bernanke's testimony before a U.S. Senate committee in July 2010). The ECB issued a monthly report on its covered bond purchase program (Monthly Report on the Euro System's Covered Bond Purchase Program ) through the period when the program is active, while the BoE has published an Asset Purchase Facility Quarterly Report since April 2009.

\section{B. Policy Coordination}

5. Financial stability balance sheet policies should be complemented by supervisory and regulatory measures and consistent with the crisis management strategy. 
124. The central banks' counterparties should be limited to regulated and solvent financial institutions. However, when the central banks provide market liquidity support, in response to market strains, there are risks that some financial institutions face not a temporary illiquidity constraint but a solvency problem. Accordingly, the central banks should have timely access to supervisory information about the financial conditions of each of their counterparties. In case of insolvency problem, a bank supervisor and the government should be responsible for supporting or resolving insolvent financial institutions, through various crisis management measures, such recapitalization, purchases and assumptions, and bad bank approach.

\section{Application}

- $\quad$ The Fed and the Treasury issued a joint statement, on March 23, 2009, clarifying that the Fed's lender-of-last-resort lending should be against collateral with the aim of improving financial or credit conditions broadly and should avoid credit risk and allocation. On May 6, 2009, in the announcement of the Treasury Capital Assistance Program and the Supervisory Capital Assessment Program, key supervisors in the United States, including Treasury and the Fed, stated that the Treasury should be responsible for capital injection.

- In several economies, central banks' role in crisis management is set out in the central bank legislation or policy statements (e.g., the Bank of Canada). Generally, the central banks' role is confined to providing emergency liquidity with adequate collateral to troubled financial institutions, while fiscal authorities are responsible for capital support.

6. Central banks' balance sheet policies should be clearly delineated from fiscal policies.

125. Balance sheet policies may have much larger budgetary implications for the government than conventional policies. For example, purchasing large amounts of public sector debts by the central banks contributes to lowering yields of public securities, which is also desirable from the perspective of the government's debt management. However, once the central banks' policy focus shifts to tightening, there could be a conflict of interest between the central banks and fiscal authorities. ${ }^{41}$ Some balance sheet policies, such as the purchase of large amounts of private sector securities posing market risk and the remuneration of bank reserves, also have budgetary implications.

126. Accordingly, policymakers should agree on a distinction between monetary and fiscal operations to ensure that the appropriate institution is accountable for its actions and policies are implemented most effectively. Such a clear demarcation is also important to ensure central bank autonomy, particularly because the autonomy is often granted specifically to central banks' monetary policy functions.

\footnotetext{
${ }^{41}$ See Code of Good Practices on Transparency in Monetary and Financial Policies, principles 1.2 and 1.3 Guidelines for Public Debt Management, Summary of the Debt management Guidelines, Section 1.3 coordination with monetary and fiscal policies.
} 


\section{Best practices}

- $\quad$ Many central banks are legally not allowed to purchase government securities in the primary markets (e.g., the BoJ). In the Euro area, the Treaty on the Functioning of the European Union prohibits any type of central bank lending to governments.

- Central bank senior officials occasionally explained to the public that balance sheet policies are not to monetize fiscal deficits (e.g., Federal Reserve Chairman Bernanke’s speech of May 25, 2010; and BOE Deputy Governor Bean’s answer on quantitative easing).

- When the BOE launched an asset purchase program, in response to the request by BOE Governor, the Chancellor of the Treasury confirmed that the government's debt management policy would be consistent with the aim of the BOE's monetary policy and the government would not change its debt management strategy taking account of the BOE's asset purchase program.

\section{Operational Designs and Exit Strategies}

7. Central banks should have sufficient legal and operational flexibility for balance sheet policies.

127. The operational flexibility granted by central bank law is important when the range of operations needs to be expanded, especially in a crisis situation. The operational sphere of balance sheet policies can also shift with changes in the structure of the financial sector. Accordingly, legal and operational frameworks of central banks need to keep up with these changes.

\section{Best practices}

- $\quad$ The old Bank of Canada Act limited the range of central bank operations. As a result, the central bank faced legal constraints in expanding eligible collateral for its liquidity operations. To give the central bank more legal flexibility in conducting open market operations, the Bank of Canada Act was amended on August 5, 2008.

\section{Balance sheet policies should be designed to minimize distortions, including moral} hazard and resource misallocation.

128. In most cases, balance sheet policies alter the relative price of assets and financing conditions of counterparties and related markets by more than conventional monetary policies. In this sense, balance sheet policies have inherently distortionary impacts. Balance sheet policies should be conducted in a way that such distortionary impacts may neither last unnecessarily long nor exceed the expected benefits. To this end, financial stability policies should build in incentive mechanisms to prevent their misuse by counterparties. 
129. Asset purchase programs for macroeconomic stability purpose should be conducted in markets deep and liquid enough to prevent the central banks' intervention from substantially impairing the market function. In the conduct of credit support for macro-stability purposes, central banks should not be involved in selecting individual borrowers or particular economic sectors as distortionary impacts are extremely high.

\section{Best practices}

- $\quad$ For most of market liquidity support measures, involving private sector assets, the central banks generally charged higher interest rates or set the purchase prices at a level attractive only under stressed market conditions (e.g., the Fed's CPFF and TALF, BOJ's corporate bonds and commercial paper purchase facility and BOE's commercial paper purchase facility).

- $\quad$ Advanced economy central banks have designed liquidity or credit support measures - either for financial stability purposes or macro-stability purposes - in a way the central banks are not directly involved in the selection of eligible nonfinancial enterprises, projects, or securities. Instead, the central banks set predetermined criteria (industrial categories, size of the assets, credit ratings, etc.. e.g., the Fed's $\underline{\text { CPFF }}$ and TALF and BOJ's Fund-Provisioning Measure to Support Strengthening the Foundations for Economic Growth).

- In March 2009, ${ }^{42}$ in the face of "the very weak economic outlook," the Fed decided to expand MBS purchases expecting that it would provide "greater benefits to the housing sector, and on private borrowing rates more generally,” while also acknowledging that "purchases of Treasury securities...minimize the Federal Reserve's influence on the allocation of credit.” Later in August 2010, the Fed decided to reinvest principal payments from MBS in Treasury securities motivated by the idea to "minimize the extent to which the Federal Reserve portfolio might be affecting the allocation of credit among private borrowers and sectors of the economy." 43

\section{Exit strategies from balance sheet policies should be developed and clearly} communicated at the time of their introduction.

130. Balance sheet policies should be implemented on a conditional basis for a limited duration and with a clearly communicated exit strategy to avoid unintended side effects, such as distortion to resource allocations and risks of moral hazard and central bank balance sheet. However, at the same time, unwinding the balance sheet measures should be done gradually and cautiously to preserve market confidence. In particular, if exit dates are preannounced, policymakers need to monitor carefully progress in the wide range

\footnotetext{
${ }^{42}$ See "Minutes of the Federal Open Market Committee March 17-18, 2009."

${ }^{43}$ See "Minutes of the Federal Open Market Committee April 27-28, 2010."
} 
of crisis intervention policies and stand ready to alter the dates, if needed. Accordingly, an exit strategy is developed, initially at the time of introduction of balance sheet measures and updated as situations evolve, in close collaboration with other relevant government agencies (e.g., bank supervisors).

\section{Best practices}

- $\quad$ Most central banks that introduced balance sheet measures during the crisis time explained their exit strategies well before actual exits commenced (e.g., Fed Chairman Bernanke, February 2010, ECB President Trichet, September 2009, and BoJ Policy Board Member Mizuno, August 2009).

- $\quad$ At the time launching its balance sheet measures, the Fed announced their explicit expiration dates, conditional on improvements in market conditions, except for few measures.

- $\quad$ Many financial stability balance sheet policies, such as the Fed's CPFF, TALF, BoE's APF (corporate bonds and commercial paper), and the Riksbank's term loan facility, include penal pricing to encourage banks to exit from central banks’ liquidity facilities.

- $\quad$ On bond purchase programs, the Fed and ECB announced both the size of the program and the expected completion date, while the BoE announced only the size of the program.

\section{Central Bank Balance Sheet Protection}

10. For lending operations, risk management tools, such as collateral, pricing, and haircuts, should be used based on the differential risks of each policy.

131. When a central bank conducts balance sheets policies by extending loans to its counterparties, taking collateral is the most common way to reduce the financial risks of the credit extension. During the crisis period, many central banks broadened the range of eligible collateral but for the newly accepted collateral, if less creditworthy or less liquid, a higher haircut reflecting these risks should be applied to minimize the credit risks.

\section{Best practices}

- $\quad$ The Fed established a framework for collateral eligibility, valuation, and haircuts for each balance sheet policy program.

- $\quad$ The BoJ introduced several new liquidity facilities consistent with the principles of its collateral policy: namely (i) maintaining the soundness of the BoJ's assets-with a view to maintaining the soundness of the BoJ's assets, the BoJ shall only accept collateral with sufficient creditworthiness and marketability; (ii) ensuring smooth business operations of the BoJ and efficient use of collateral; and (iii) utilizing market information - the BoJ shall make effective use of market information, such as ratings 
in assessing the eligibility of collateral, market prices in calculating collateral prices, and public information in evaluating the creditworthiness of collateral.

11. Private debt instruments for outright purchase or collateral for lending operations should be high quality.

132. When a central bank conducts balance sheets policies by purchasing securities outright, the credit is secured only by the asset purchased. Thus the securities should be high quality investment grades to protect the central bank's balance sheet.

\section{Best practices}

- $\quad$ On the Fed's $\underline{\mathrm{CPFF}}$, the eligible assets were limited to U.S. dollar-denominated commercial paper, including asset-backed commercial paper, with ratings at least A1/P-1/F1 by a major nationally recognized statistical rating organization, and for its $\underline{\text { MIFF }}$, eligible financial institutions were limited to those with a short-term debt rating of at least A-1/P-1/F1 from two or more major nationally recognized statistical rating organizations.

- $\quad$ On the ECB's covered bond purchase program, eligible assets should have a minimum rating of AA or equivalent by at least one of the major rating agencies (Fitch, Moody’s, S\&P or DBRS) and, in any case, not lower than BBB-/Baa3.

- $\quad$ On the BoJ's commercial paper purchase program, eligible assets are only those issued by a company rated a-1 by a rating agency.

12. The central banks should have sufficient financial strength and the extent of their risk taking should be agreed with the government, including an ex ante mechanism to transfer resources to the central bank if needed.

\section{Rational}

133. Central banks should have sufficient capital and reserves to absorb any losses arising from balance sheet policies. ${ }^{44}$ In determining the size of the capital and reserves, the central bank needs to evaluate the size of potential losses, their probabilities, and income generating capacity (i.e., segniorage). The central banks' dividend policies should also be designed to ensure their financial strength, and accounting rules should also allow for appropriate provisioning of expected losses. To preserve financial autonomy, central banks should not introduce balance sheet policies whose potential financial risks could exceed their financial strength, and central bank operations should be confined by the level of its capital and reserves. The central banks and the government should agree on the burden sharing of potential losses.

134. The central bank's capital may be reduced by losses arising from balance sheet policies. In anticipation of such a risk, a clear rule for central bank recapitalization by the

${ }^{44}$ For detailed discussion, see Peter Stella (2008). 
government-including the trigger condition for recapitalization, instruments (typically marketable securities with market interest rates), and timing—should be established.

\section{Best practices}

- $\quad$ On December 16, 2010, the ECB decided to increase its subscribed capital by €5 billion, from $€ 5.76$ billion to $€ 10.76$ billion, in view of increased volatility in foreign exchange rates, interest rates and gold prices, as well as credit risk.

- $\quad$ The BoE has implemented an asset purchase facility with the authorization of the Treasury. Prior to the launch of this program, the government, in the open letters between the Chancellor of the Treasury and the Governor of the BOE, agreed to indemnify the BoE and a fund specifically created for this facility from any losses arising out of or in connection with the facility.

- $\quad$ The Fed established a special purpose vehicle (TALF LLC ) to purchase and manage any assets received by the New York Fed in connection with any TALF loans. TALF LLC purchased all such assets at a price equal to the TALF loan, plus accrued but unpaid interest, with the funds first through the fees received by TALF LLC and any interest TALF LLC has earned on its investments. In the event that such funding proves insufficient, the U.S. Treasury's Troubled Asset Relief Program (TARP) will provide additional subordinated debt funding to TALF LLC to finance up to $\$ 20$ billion of asset purchases.

13. Measures to protect central bank balance sheets should be clearly communicated.

135. Central banks face greater financial risks in implementing balance sheet policies than in implementing conventional monetary policy. Central banks should not only have appropriate risk management framework in place in implementing balance sheet policies but should also clearly communicate it. This is important to assure the public that balance sheet policies embed appropriate measures to protect the financial position of the central banks, which is important to ensure its policy autonomy.

\section{Best practices}

- $\quad$ The measures to protect central bank balance sheets described in 10 and 11 and the arrangements with the government to secure its financial strength have been made public. 